\title{
Habranthus (Amaryllidaceae) do Brasil
}

\author{
Habranthus (Amaryllidaceae) of Brasil
}

\author{
Andrielle Câmara Amaral-Lopes ${ }^{1,2,4}$, Taciana Barbosa Cavalcanti ${ }^{3}$
}

\begin{abstract}
Resumo
Habranthus é um gênero com forte apelo ornamental e apresenta de 30 a 40 espécies distribuídas desde o sudeste dos Estados Unidos, México até a América do Sul. Sua delimitação, bem como das espécies, é confusa e a taxonomia é complicada, com vários casos de tipificação necessitando serem esclarecidos. Os objetivos deste estudo foram realizar o levantamento das espécies brasileiras de Habranthus do Brasil e apresentação de descrições, ilustrações, chave de identificação e comentários para todas as espécies. Foram identificadas 21 espécies cujas distribuições abrangem os domínios fitogeográficos da Caatinga, Cerrado, Mata Atlântica e Pantanal, ocorrendo em vegetação de caatinga arbustivo-arbórea, campo rupestre, carrasco, mata de galeria, campo limpo, cerrado sensu stricto, cerrado de altitude e em locais alagáveis.
\end{abstract}

Palavras-chave: Habranthus, florística, Brasil, taxonomia, plantas bulbosas ornamentais.

\begin{abstract}
Habranthus is an ornamental genus with 30-40 species distributed from the southeastern United States and Mexico to South America. Genus and species delimitation are confusing with several situations that need to be clarified. The aim of this study was to conduct a survey of the Brazilian species of Habranthus, and contribute to the knowledge of these species through descriptions, illustrations, identification key and comments on all species. Twenty one species were identified, distributed in Caatinga, Cerrado, Atlantic Forest and Pantanal phytogeographic domains, inhabiting cerrado vegetation, rocky fields, gallery forest, grassland, flooded and disturbed areas.
\end{abstract}

Key words: Habranthus, floristic inventories, Brazil, taxonomy, ornamental bulbous plants.

\section{Introdução}

Amaryllidaceae J. St.-Hil. está dividida em três subfamílias: Agapanthoideae, Allioideae e Amaryllidoideae (Chase et al. 2009). Os 51 gêneros da família apresentam distribuição cosmopolita, entretanto é predominantemente tropical (Meerow et al. 1999 2000). Na Região Neotropical, a família está representada por cerca de 30 gêneros, ocorrendo no México, América Central e América do Sul. Segundo Meerow (2004) o Brasil, Chile e os Andes no Equador e Peru apresentam áreas de notável diversidade, onde Hippeastrum Herb. (50-60 espécies), Hymenocallis Salisb. e Zephyranthes Herb. (ca. 50 espécies cada) e Clinanthus Herb. (ca. 30 espécies) são os gêneros com maior número de espécies. No Brasil, Amaryllidaceae está representada por cerca de 15 gêneros e 150 espécies, sendo Cearanthes Rav., Griffinia KerGawler, Tocantinia Rav. e Worsleya (W. Watson ex Traub) Traub, gêneros endêmicos (Meerow \& Snijman 1998)

Há controvérsias entre os autores em relação à delimitação dos gêneros na família. As classificações para Amaryllidaceae ainda não estão perfeitamente estabelecidas, sendo frequentemente reestruturadas, de forma que ainda não há um modelo estável, limites precisos, bem definidos e difundidos no meio científico. Isto se reflete também dentro dos gêneros nativos brasileiros, para os quais o número total de espécies e suas delimitações taxonômicas ainda carecem de elucidação.

\footnotetext{
${ }^{1}$ Parte do estudo realizado no curso de Doutorado em Botânica da Universidade de Brasília, UnB, Campus Universitário Darcy Ribeiro, 70910-900, Brasília, DF. ${ }^{2}$ Embrapa Hortaliças, Rodovia Brasília/Anápolis BR-060 km 09, C.P. 218, 70359-970, Gama, DF.

${ }^{3}$ Embrapa Recursos Genéticos e Biotecnologia, Embrapa Cenargen, SAIN, Parque Estação Biológica, C.P. 02372, 70.770-917, Brasília, DF.

${ }^{4}$ Autor para correspondência: andrielle.lopes@embrapa.br
} 
Habranthus Herb. pertencente à tribo Hippeastreae Herb. ex Sweet de Amaryllidoideae, apresentando entre 30 e 40 espécies, distribuídas desde o sudeste dos Estados Unidos e México até a América do Sul (Meerow \& Snijman 1998; Flagg et al. 2007). Os representantes do gênero são caracterizados pela presença de bulbos perenes, folhas anuais, brácteas fundidas em tubo, flores zigomorfas e estames em quatro comprimentos diferentes. As espécies ocorrem em campos, matas, cerrados e em locais alagáveis dos domínios fitogeográficos da Caatinga, Cerrado, Mata Atlântica e Pantanal.

A identificação das espécies brasileiras de Habranthus é em geral dificultada, pois muitas foram descritas apenas baseadas na parte reprodutiva, a partir do material herborizado, muito em função de algumas espécies não apresentarem folhas durante o período fértil. Além disso, a delimitação do gênero é às vezes controversa com relação a Zephyranthes. Há uma grande dúvida entre os estudiosos da família sobre a separação morfológica entre esses dois gêneros devido à similaridade na estrutura floral, ocorrência simpátrica e falta de caracteres satisfatórios para separar os dois gêneros, o que levou a diferentes delineamentos genéricos e infragenéricos e multiplicidade de transferências de espécies entre Habranthus e Zephyranthes. A diferença estaria na simetria da flor, sendo Zephyranthes caracterizado por apresentar flores actinomorfas, eretas, com estames eretos de mesmo comprimento, enquanto Habranthus teria flores zigomorfas, declinadas, estames declinados e de diferentes comprimentos (Dutilh \& Assis 2005). Essa foi a delimitação adotada nesse trabalho.

A única obra que trata as espécies brasileiras de Habranthus de forma geral é o trabalho de Seubert (1847) na "Flora Brasiliensis", onde não constam chaves de identificação ou pranchas e apresenta caracterizações genéricas e específicas. A maioria das espécies brasileiras foi descrita por Ravenna (1988, 1999a, 1999b, 2001, 2002) estando mal caracterizadas e com problemas de tipificação. Por estes motivos, as espécies brasileiras encontramse, na grande maioria, mal delimitadas.

Estudos mais recentes e expressivos são os de Arroyo (1990) realizados para a Argentina e Uruguai, que incluem espécies que ocorrem no Brasil, Oliveira (2006), para a Cadeia do Espinhaço, Dutilh \& Assis (2005) para a Flora de São Paulo e Dutilh \& Oliveira (2013) para a Flora do Brasil.
O presente estudo apresenta o levantamento das espécies de Habranthus ocorrentes no Brasil cujos resultados foram embasados em observações de material depositado em herbário, das espécies em campo e em casa de vegetação e incluem descrições detalhadas, ilustrações, comentários taxonômicos e chave de identificação para as espécies.

\section{Materiais e Métodos}

O levantamento bibliográfico reuniu um total de 40 protólogos e outros 40 artigos relacionados ao gênero. Trinta materiais-tipo foram analisados, obtidos por empréstimo de herbários nacionais e internacionais, além de outros de outros espécimes, cujos acrônimos são citados segundo o Index Herbariorum (Thiers, continuamente atualizado), BHCB, CEN, CESJ, CH, ESA, FLAS, FTG, HB, HUEFS, IBGE, INPA, MBM, MO, NY, PACA, RB, SGO, SP, SPF, TEPB, UB, UEC, UFG, US. Para as espécies com um número elevado de material apenas um espécime de cada localidade foi listado no material examinado, e em função disso, foi adotada a terminologia "material selecionado". O estudo foi também embasado em trabalho de campo através do qual 21 expedições foram realizadas. O material fértil foi prensado e as flores tiveram as suas peças montadas separadamente em cartão com fita adesiva transparente, de forma esquemática, segundo a técnica apresentada por Amaral (2007). O material coletado foi incorporado ao Herbário CEN.

Bulbos de espécimes foram coletados, mantidos vivos e cultivados em casa de vegetação da Embrapa Recursos Genéticos e Biotecnologia, em Brasília. Em casa de vegetação puderam ser acompanhados o desenvolvimento e as fenofases das plantas, e também observadas e anotadas as características que se perdem no processo de herborização. A coleção viva de espécies de Habranthus conta atualmente com 10 espécies, representadas por populações distintas.

\section{Resultados e Discussão}

Habranthus Herb. Botanical Magazine t. 2464. 1824. Espécie-tipo: Habranthus gracilifolius Herb. Bot. Mag. t. 2464.

Bulbos perenes, subterrâneos, ovais ou globosos, tunicados, negros ou marrons, às vezes continuado em um colo alongado. Folhas anuais ou persistentes, dísticas, sésseis, eretas ou declinadas, lisas, raramente excedendo ca. 2 cm larg., lineares, filiformes. Escapo fistuloso, cilíndrico; brácteas espatáceas unidas na porção 
proximal formando um tubo; bractéolas às vezes presentes; inflorescências geralmente unifloras, raramente 2-flora. Flores amarelas, brancas, róseas, lilases ou vermelhas, declinadas a sub-eretas, zigomorfas, infundibuliformes a campanuladas; pedicelo geralmente presente; tubo do hipanto formado pelas tépalas basalmente conatas, estas com comprimento diferente, e adnatas aos filetes; paraperigônio geralmente presente, formado por segmentos em forma de gancho, denteados, setiformes, fimbriado ou por calosidades; filetes filiformes, fasciculados a semi-fasciculados, declinados, distalmente recurvados, em até 4 comprimentos; anteras linearoblongas, geralmente paralelas à linha central da flor; ovário ínfero, estilete filiforme; estigma trífido ou trilobado, lóbulos lineares. Cápsulas loculicidas, 3-locular, depresso-globosas; sementes papiráceas, aladas, arredondadas a deltóides, marrom-escuras a negras.

\section{Chave artificial de identificação para as espécies de Habranthus ocorrentes no Brasil}

1. Flores violetas, roxas, púrpuras ou vermelhas.

2. Flores infundibuliformes; tépalas internas com ápice agudo a cuspidado.

3. Tépalas violetas, roxas ou púrpuras; tubo do hipanto 4-10 $\mathrm{mm}$ compr.; anteras $4-5 \mathrm{~mm}$ compr., reniformes; estigma trilobado.

4. Bractéolas ausentes; brácteas verde-claras a acinzentadas; bulbos globosos; folhas presentes durante a floração. Ápice das tépalas internas agudo e das externas com apículo conspícuo.

3. H. bahiensis

4'. Bractéolas presentes; brácteas verde-avermelhadas; bulbos ovais; folhas ausentes durante a floração. Ápice das tépalas internas cuspidado e das externas acuminado

20. H. ruber

3'. Tépalas vermelhas; tubo do hipanto ca. $23 \mathrm{~mm}$ compr.; anteras ca. $6 \mathrm{~mm}$ compr., elípticas; estigma trífido 6. H. conterminus

2'. Flores crateriformes; tépalas internas com ápice acuminado.

5. Folhas ausentes durante a floração. Tubo do hipanto 8,5-9 mm compr.; paraperigônio ausente; anteras maiores que $6 \mathrm{~mm}$ compr. 9. H. goianus

5'. Folhas presentes durante a floração. Tubo do hipanto 15-20 mm compr.; paraperigônio presente; anteras até $5 \mathrm{~mm}$ compr.

21. H. sylvaticus

1. Flores amarelas, brancas, rosas ou lilases.

6. Flores amarelas com nervuras ocre, campanuladas; pedicelo até $1 \mathrm{~cm} \mathrm{cmpr}$.

1. H. andersonii

6'. Flores brancas, rosas ou lilases, infundibuliformes ou crateriformes; pedicelo maior que $1 \mathrm{~cm}$ compr.

7. Folhas presentes durante a floração. Tubo do hipanto até $6 \mathrm{~mm}$ compr.

8. Folhas filiformes

9. Folhas até 6-nervadas; pedicelos verdes ou verde-claros.

10. Paraperigônio presente; ovário elíptico. Tépalas do verticilo externo com 12-16 nervuras principais, tépalas do verticilo internocom 9-11 nervuras principais.

11. Escapo 4,5-15 cm compr.; pedicelo até $3 \mathrm{~cm}$ compr.; flores com até 4 cm compr.; paraperigônio formado por segmentos setiformes; filetes em 4 comprimentos diferentes.

12. Estigma trilobado; flores crateriformes

2. H. araguaiensis

12'. Estigma trífido; flores infundibuliformes

5. H. concinnus

11. Escapo 20-32 cm compr.; pedicelo maior que $3 \mathrm{~cm}$ compr.; flores maiores que $4 \mathrm{~cm}$ compr.; paraperigônio denteado; filetes em 2 comprimentos diferentes

10'. Paraperigônio ausente; ovário globoso. Tépalas externas com 9 nervuras principais, tépalas internas com5 nervuras principais. 
9'. Folhas ca. 10-nervadas; pedicelos verde-vináceos 11. H. irwinianus

8'. Folhas lineares

13. Folhas com até $8 \mathrm{~cm}$ compr. durante a floração.

14. Filetes em 4 comprimentos diferentes.

15. Brácteas 2,5-3,5 cm compr. Pedicelo 3-5,2 cm compr.; flores 4,7-7 cm compr.; paraperigônio formado por franjas de fimbrias digitiformes.

16. Bulbos ovais, ca. $2,5 \mathrm{~cm}$ compr. Folhas 9-11-nervadas; tépalas superiores com cintura, 4-4,5 cm compr., tépalas internas com 7-9 nervuras principais

4. H. botumirimensis

16'. Bulbos globosos, 3,5-4 cm compr. Folhas 14-nervadas; tépalas superiores sem cintura, ca. 5,2 cm compr., tépalas internas com 10-13 nervuras principais ..

7. H. datensis

15'. Brácteas 1,8-1,9 cm compr. Pedicelo 1,5-1,8 cm compr.; flores ca. $3,5 \mathrm{~cm}$ compr.; paraperigônio formado por segmentos setiformes 17. H. pantanalensis

14'. Filetes em 2 comprimentos diferentes.

17. Flores crateriformes; paraperigônio formado por calosidades

12. H. itaobinus

17'. Flores infundibuliformes; paraperigônio formado por fímbrias

14. H. lucidus

13'. Folhas a partir de $11 \mathrm{~cm}$ compr. durante a floração.

18. Bulbos globosos; brácteas a partir de $3 \mathrm{~cm}$ compr. Flores crateriformes, tépalas externas 20-24-nervadas; filetes em 4 comprimentos diferentes; estigma trilobado.

19. Colo do bulbo ca. 1,5 cm compr. Folhas 9-nervadas; bractéolas ausentes; paraperigônio ausente ou inconspícuo 10. H. gracilifolius

19'. Colo do bulbo 2-7 cm compr. Folhas 12-20-nervadas; bractéolas presentes; paraperigônio presente, segmentos filiformes 19. H. robustus

18'. Bulbos ovais; brácteas ca. $2 \mathrm{~cm}$ compr. Flores infundibuliformes, tépalas externas 11-15-nervadas; filetes em 2 comprimentos diferentes; estigma trífido.

18. H. pedunculosus

7'. Folhas ausentes durante a floração. Tubo do hipanto 7-22 mm compr.

20. Bulbos ovais, colo maior que 3,5 cm compr.; lobos das brácteas até $0,8 \mathrm{~cm}$ compr.

8. H. gameleirensis

20'. Bulbos globosos, colo até $3 \mathrm{~cm}$ compr.; lobos das brácteas maior que 1,2 cm compr. 15. H. maranensis

1. Habranthus andersonii Herbert ex Lindl, Bot. Reg. 16: t. 1345. $1830 . \quad$ Fig. 1a-c

Bulbos globosos, 2,3-2,5 × 1,8-2 cm; colo 0,5-2 cm compr. Folhas verde-claras, lineares, ca. $30 \times 0,1-0,2 \mathrm{~cm}$, ápice agudo; nervuras não observadas. Escapos ca. $28 \times 0,4 \mathrm{~cm}$; brácteas acobreadas, ca. 2,2 cm compr.; bractéolas filiformes; pedicelo verde, ca. $8 \mathrm{~mm}$ compr. Flores campanuladas, ca. $3,4 \mathrm{~cm}$ compr.; tubo do hipanto 3-4 cm compr.; tépalas amarelas com nervuras ocre, obovais a oblanceoladas; verticilo externo com ca. 16 nervuras principais, ápice agudo, região papilar globosa; tépala superior sem cintura, 2,6$2,7 \times 1,3-1,4 \mathrm{~cm}$, tépalas laterais inferiores 2,8-2,9 $\times 1-1,2 \mathrm{~cm}$; verticilo interno com ca. 14 nervuras principais, ápice agudo; tépalas laterais superiores
2,6-2,7 $\times 0,8 \mathrm{~cm}$, tépala inferior $2,7-3 \times 0,9-1,2$ $\mathrm{cm}$; paraperigônio presente formado por segmentos filiformes, franjados; filetes em 2 comprimentos diferentes, anteras reniformes, 3-4 mm compr.; ovário elíptico; estigma trífido. Fruto não visto.

Material examinado: BAHIA: Remanso, Caminho para Pau Ferro, 9`37'18”'S, 42॰19’29”'W, 27.II.2000, f1., N.G. Jesus et al. 839 (SPF, HUEFS).

Habranthus andersonii é citado pela primeira vez para o Brasil, tendo sido anteriormente registrada apenas para o Uruguai e Argentina (Arroyo 1990). Essa espécie é de fácil identificação pelas flores campanuladas, amarelas com nervuras ocre, características ausentes em qualquer outra espécie ocorrente no Brasil. Dutilh \& Oliveira (2013) referem $H$. andersonii na sinonímia de 

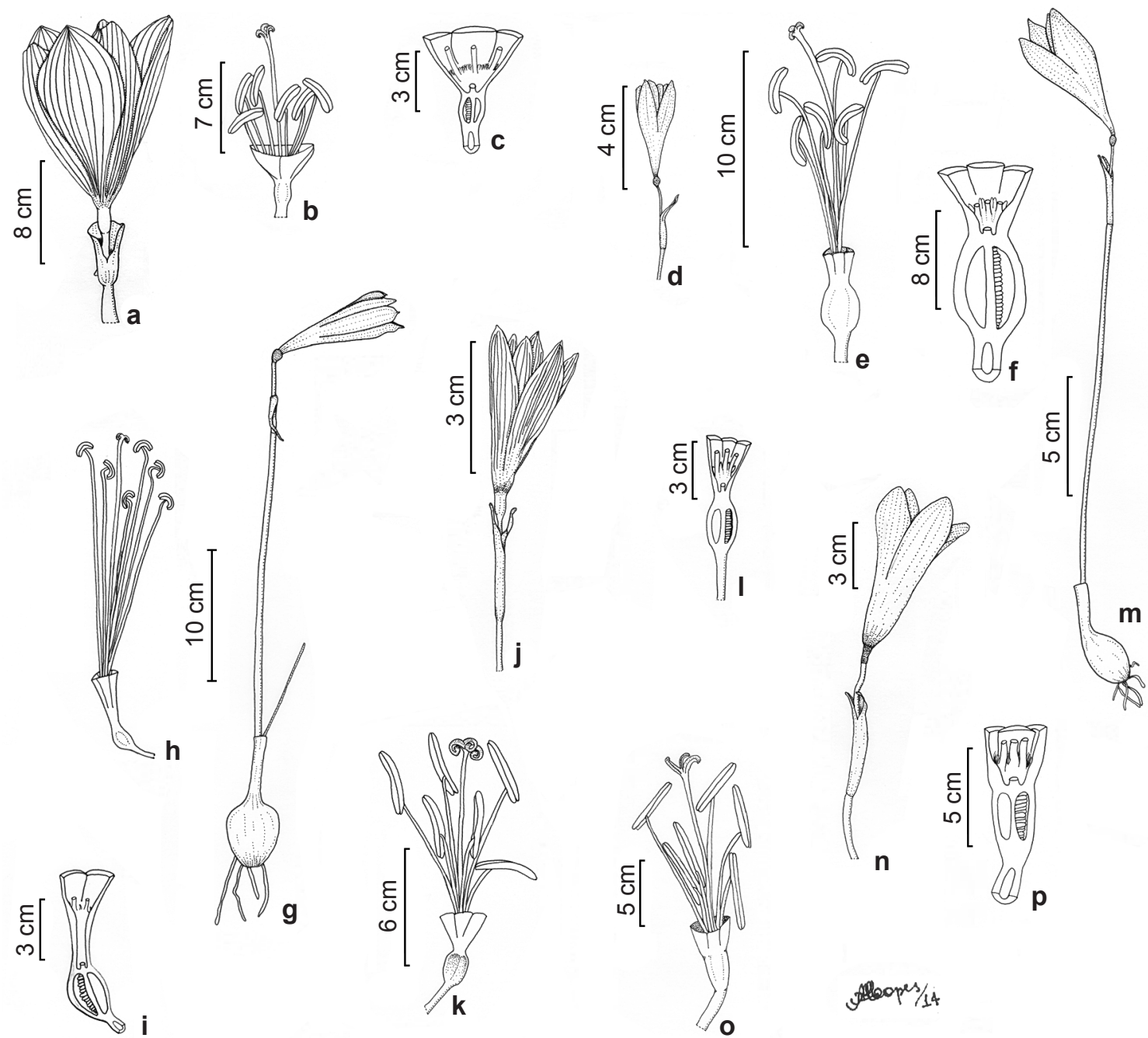

Figura 1 - a-c. Habranthus andersonii Herb. - a. flor em vista lateral; b. flor, retirada as tépalas, evidenciando estames, estilete e estigma; c. flor em corte longitudinal, evidenciando paraperigônio com segmentos filiformes (Jesus et al. 839). d-f. Habranthus araguaiensis Ravenna. - d. flor em vista lateral; e. flor, retirada as tépalas, evidenciando estames, estilete e estigma; f. flor em corte longitudinal, evidenciando paraperigônio com segmentos septiformes (Hatschbach \& Kummrow 35087). g-i. Habranthus bahiensis Ravenna - g. hábito; h. flor, retirada as tépalas, evidenciando estames, estilete e estigma; i. Flor em corte longitudinal, evidenciando paraperigônio com segmentos septiformes (Hatschbach 39682). j-1. Habranthus concinnus Ravenna - j. flor em vista lateral; k. flor, retirada as tépalas, evidenciando estames e estilete; 1. flor em corte longitudinal, evidenciando paraperigônio com segmentos septiformes (Hatschbach 19722). m. Habranthus conterminus Ravenna, hábito (Hatschbach 44098). n-p. Habranthus datensis Ravenna - n. flor em vista lateral; o. flor, retirada as tépalas, evidenciando estames, estilete e estigma; p. flor em corte longitudinal, evidenciando paraperigônio com segmentos de fímbrias digitiformes (Amaral\& Moreira 51). Ilustração de A. Amaral-Lopes.

Figure 1 - a-c. Habranthus andersonii Herb. - a. flower in lateral view; b. flower, the tepals removed, showing stamens, style and stigma; c. flower in longitudinal sectio, showing paraperigônio with filiform segments (Jesus et al. 839). d-f. Habranthus araguaiensis Ravenna - d. flower in lateral view; e. flower, the tepals removed, showing stamens, style and stigma; f. flower in longitudinal section, showing paraperigônio with setiformes segments (Hatschbach \& Kummrow 35087). g-i. Habranthus bahiensis Ravenna - g. habit; h. flower, the tepals removed, showing stamens, style and stigma; i. flower in longitudinal section, showing paraperigônio with setiformes segments (Hatschbach 35087). j-1. Habranthus concinnus Ravenna - j. flower in lateral view; k. flower, the tepals removed, showing stamens and stylus; 1 . flower in longitudinal section, showing paraperigônio with setiformes segments (Hatschbach 19722). m. Habranthus conterminus Ravenna, habit (Hatschbach 44098). n-p. Habranthus datensis Ravenna - n. flower in lateral view; o. flower, the tepals removed, showing stamens, style and stigma; $\mathrm{p}$. flower in longitudinal section, showing paraperigônio segments with fingerlike fimbriae (Amaral \& Moreira 51). Illustration A. Amaral-Lopes. 
Zephyranthes tubisphata Herb. Entretanto, as descrições originais e ilustrações de $H$. andersonii e material-tipo de Z. tubisphata foram estudados e o presente estudo conclui que a primeira se trata de uma espécie diferente. Dutilh \& Oliveira (2013) ainda consideram cinco variedades de $H$. andersonii, duas também citadas no protólogo. No entanto, nenhuma variedade foi observada nesse trabalho. Ocorre no estado da Bahia na caatinga arbustivo-arbórea, aos $400 \mathrm{~m}$ de altitude. Floresce em fevereiro.

2. Habranthus araguaiensis Ravenna. Onira 6(5): 41, 2001.

Fig. 1d-f

Bulbos arredondados 1,2-1,5 × 1,3-1,4 cm, colo 1,8-3 cm compr. Folhas verdes, filiformes, ca. $10 \times 0,5 \mathrm{~cm}$, ápice agudo; nervuras 3-4. Escapos 9-15 $\times 0,05-0,1 \mathrm{~cm}$; brácteas róseas a acinzentadas, 1,9-2,5 cm compr.; bractéolas ausentes; pedicelo verde, 1,7-2,5 cm compr. Flores crateriformes, ca. 3,1-4 cm compr.; tubo do hipanto 1-2 mm compr.; tépalas róseo-alva, oblanceoladas; verticilo externo ca. 13 nervuras principais, ápice levemente cuspidado, região papilar em faixa longitudinal; tépala superior sem cintura, ca. $3 \times 0,4 \mathrm{~cm}$, tépalas laterais inferiores 3-3,1 $\times 0,4-0,5 \mathrm{~cm}$; verticilo interno com 9-10 nervuras principais, ápice agudo; tépalas laterais superiores $2,9-3 \times 0,3-0,4 \mathrm{~mm}$, tépala inferior ca. $3,5 \times 0,4 \mathrm{~cm}$; paraperigônio presente, formado por segmentos setiformes, pareados e flanqueando os filetes na base; filetes em 4 comprimentos diferentes; anteras elípticas a reniformes, $4-5 \mathrm{~mm}$ compr.; ovário elíptico; estigma trilobado. Fruto não visto.

Material examinado: GOIÁS: Caiapônia, Serra do Caiapó, estrada Caiaponia-Jataí, $17^{\circ} 12^{\prime} \mathrm{S}, 51^{\circ} 47^{\prime} \mathrm{W}$, X.1964, fl., H.S. Irwin \& T.R. Soderstrom 7076 (UB). MATO GROSSO: Poconé, Distrito de Pirizal, Baía dos Cavalos, 8.XI.2002, fl., P.H.A. Melo \& F.A. Carvalho 131 (BHCB). TOCANTINS: Alto Araguaia, 22.IX.1974, fl., G. Hatschbach \& R. Kummrow 35087 (MBM, typus).

Habranthus araguaiensis é caracterizada pelas folhas filiformes, filetes em 4 comprimentos, ovário elíptico e paraperigônio formado por segmentos setiformes. No aspecto vegetativo, pode ser confundida em material de herbário com H. itaobinus. Habranthus itaobinus é diferenciado de $H$. araguaiensis por apresentar bulbos globosos, folhas lineares, 8-12-nervadas e paraperigônio formado por calosidades opostas à base dos filetes. Ocorre no Mato Grosso e Tocantins em áreas brejosas e solos pedregosos, aos 150-700 m de altitude. Floresce de setembro a novembro.
3. Habranthus bahiensis Ravenna. Onira 1(8): 53-56, 1988.

Fig. 1g-i

Bulbos globosos, 2-4 × 2-3,5 cm, colo $1,5-2,5 \mathrm{~cm}$ compr. Folhas verdes, filiformes, ca. $10 \times 0,1 \mathrm{~cm}$, ápice agudo; nervuras 6-8. Escapos $12-28 \times 0,2-0,5 \mathrm{~cm}$; brácteas verdeclaras a acinzentadas, $3-4,5 \mathrm{~cm}$ compr.; bractéolas ausentes; pedicelo verde-avermelhado, 2-4 cm compr. Flores infundibuliformes, 4-7 cm compr.; tubo do hipanto 4-5 mm compr.; tépalas violetas a púrpuras, oblanceoladas; verticilo externo com 11-14 nervuras principais, ápice com apículo conspícuo, região papilar em faixa longitudinal; tépala superior sem cintura, 4,6-6,3 ×0,8-1,2 cm, tépalas laterais inferiores $4,5-6,3 \times 0,8-1,2 \mathrm{~cm}$, verticilo interno com 9-12 nervuras principais, ápice agudo; tépalas laterais superiores 4,5-6,5 $\times 0,6-1 \mathrm{~cm}$, tépala inferior $4,2-6,3 \times 0,8-1,2 \mathrm{~cm}$; paraperigônio presente, formado por segmentos setiformes recurvados, pareados e flanqueando os filetes na base; filetes em 4 comprimentos diferentes, anteras reniformes, 4-5 mm compr.; ovário oboval; estigma trilobado. Fruto não visto. Material selecionado: BRASIL. BAHIA: Morro do Chapéu, $11^{\circ} 35^{\prime}$ 'S, $41^{\circ} 13^{\prime}$ 'W, 28.XI.1992, fl., M.M. Arbo et al. 5374 (SPF, UEC); idem, Morrão, 16.I.1977, G. Hatschbach 39682 (MBM, Lectótipo; duplicata K); São Desidério, Fazenda Palmeiral, 1.III.2003, fl., A. AmaralSantos 1780 (CEN); Queimadas, BR 242, 10km antes de Queimadas, $12^{\circ} 21$ ' 12 "S, $42^{\circ} 29^{\prime} 16^{\prime \prime} \mathrm{W}$, 7.II.2004, fl., $C$. Van den Berg et al. 1159 (HUEFS, UEC).

Habranthus bahiensis é caracterizada pelas flores violeta a purpúreas. Difere de outras espécies com flores da mesma cor como $H$. leptandrus Ravenna, originária da Bolívia, por esta apresentar anteras mais curtas e folhas extremamente finas, de H. irwinianus, de Minas Gerais, pela coloração verde-clara a acinzentada das brácteas, presença de bractéolas, tépalas róseas a lilases e paraperigônio presente, formado por segmentos setiformes recurvados. Registrada para Bahia em campo rupestre, carrasco e raro em áreas alagáveis, aos 400-580 m de altitude. Floresce nos meses de novembro e fevereiro, março.

4. Habranthus botumirimensis R. S. Oliveira. Kew Bulletin 64: 537-541, 2009.

Bulbos ovais, ca. 2,5 $\times 2,3 \mathrm{~cm}$, colo ca. 2,5 $\mathrm{cm}$ compr. Folhas verdes, lineares, ca. $4 \times 0,3 \mathrm{~cm}$, ápice agudo; nervuras 9-11. Escapos 9,5-15 × 0,1-0,2 cm; brácteas rosadas, 2,5-2,8 cm compr.; bractéolas ausentes; pedicelo verde, 4,5-5,2 cm compr. Flores infundibuliformes, 4,7-5,5 cm 
compr.; tubo do hipanto 2-3 mm compr.; tépalas róseas, oblanceoladas; verticilo externo com 15-19 nervuras principais, ápice mucronado, região papilar oval; tépala superior com cintura, 4-4,5 × $0,8 \mathrm{~cm}$, tépalas laterais inferiores não observadas; verticilo interno com 7-9 nervuras principais, ápice arredondado, tépalas laterais superiores 3,8-4,4 $\times 0,8-1 \mathrm{~cm}$, tépala inferior $3,8-4,4 \times 0,8-1 \mathrm{~cm}$; paraperigônio presente, formado por franjas de fimbrias digitiformes; filetes em 4 comprimentos diferentes, anteras oblongas, 4-5 mm compr.; ovário oboval; estigma trilobado. Fruto não visto. Material examinado: MINAS GERAIS: Botumirim, Estrada Botumirim-Barrocão, ca. 3 km de Adão Colares, 30.IX.1997, fl., A. Rapini et al. 364 (SPF, Holotypus).

Habranthus botumirimensis pode ser confundida com $H$. irwinianus quando herborizada em função das flores infundibuliformes, róseas. Entretanto, H. irwinianus apresenta bulbos globosos, folhas filiformes e paraperigônio formado por segmentos setiformes eretos. Ocorre em Minas Gerais na caatinga, cerrado e campo rupestre aos 840-860 m de altitude. Floresce em setembro. Classificada como criticamente em perigo à nível regional (Oliveira \& Sano 2009).

5. Habranthus concinnus Ravenna. Onira 3(17): 63, 1999

Fig. $1 \mathrm{j}-1$

Bulbos globosos, 0,9-1,4 × 1-1,3 cm, colo 0,6-4 cm compr. Folhas verdes, filiformes, ca. $16,5 \times 0,05 \mathrm{~cm}$ compr., ápice agudo; nervuras 3-6. Escapos 4,5-14 × 0,05-0,2 cm; brácteas castanhas com base vinácea, 1,2-2,8 cm compr.; bractéolas ausentes; pedicelo verde, 1,5-2,5 cm compr. Flores infundibuliformes, 2,1-3,8 cm compr.; tubo do hipanto 1-3 mm compr.; tépalas rosas a lilases, oblanceoladas; verticilo externo com 12-14 nervuras principais, ápice agudo a levemente cuspidado, região papilar longitudinalmente concentrada no ápice, tépala superior ca. 3,5 ×0,8 $\mathrm{cm}$, tépalas laterais inferiores 3,4-3,7 $\times 0,7 \mathrm{~cm}$, verticilo interno com ca. 9 nervuras principais, ápice agudo; tépalas laterais superiores ca. 3,5 × 0,7 $\mathrm{cm}$, tépala inferior ca. $3,3 \times 0,8 \mathrm{~cm}$; paraperigônio presente, formado por segmentos setiformes eretos; filetes em 4 comprimentos diferentes, anteras reniformes, 3-7 mm compr.; ovário elíptico; estigma trífido. Fruto não visto.

Material examinado: PARANÁ: Balsa Nova, Ponte dos Arcos, 3.VI.2005, fl. C. Koreza \& R. Kersten 2205 (MBM); Curitiba, próximo ao Capão da Imbuia, 2.VIII.1962, s.col. 127 (MBM); Lapa, Rio Passa Dois, 15.IX.1968, fl., G. Hatschbach 19722 (MBM); Ponta
Grossa, Rio Verde, Capão da Onça, 11.X.1967, fl., G. Hatschbach 17417 (MBM); Porto Amazonas, Rod. BR 277, Rio dos Papagaios, 21.IX.1990, fl., G. Hatschbach \& P. Ravenna 54460 (MBM, typus); São José dos Pinhais, Rio Pequeno, 12.XII.1969, fl., G. Hatschbach 23195 (MBM).

Habranthus concinnus, pelas tépalas rosas a lilases e pelo curto perigônio, é semelhante a $H$. coeruleus, da Argentina e H. irwinianus, de Minas Gerais. Diferem principalmente por H. coeruleus não apresentar folhas durante a floração, apresentar folhas 10-nervadas, bractéolas nas flores e estigma trilobado e por $H$. irwinianus apresentar anteras oblongas e estima trilobado. Registrada para o Paraná na Floresta Atlântica, em campos, encostas e locais úmidos, em solo pedregoso, aos 840-950 m de altitude. Floresce em junho, setembro, outubro e dezembro. Classificada como em perigo (Fundação Biodiversitas 2005).

6. Habranthus conterminus Ravenna. Onira 3(16): 57, 1999 Fig. $1 \mathrm{~m}$

Bulbos globosos, 2-4 × 2-2,5 cm, colo 2,3-4,5 cm compr. Folhas ausentes durante a floração, não observadas. Escapo 14,5-22 × 0,2$0,5 \mathrm{~mm}$; brácteas castanhas, 3,5-4,5 cm compr.; bractéolas ausentes; pedicelo verde-claro, 3,2-5 $\mathrm{cm}$ compr. Flores infundibuliformes, 7,2-10,5 cm compr.; tubo do hipanto ca. 2,3 cm compr.; tépalas vermelhas com base esverdeada, oblanceoladas; verticilo externo com 12-13 nervuras principais, ápice agudo, região papilar não observada; tépala superior sem cintura, ca. $7,8 \times 1,3 \mathrm{~cm}$, tépalas laterais inferiores $6,8-7,6 \times 1,3 \mathrm{~cm}$; verticilo interno com ca. 10 nervuras principais, ápice agudo; tépalas laterais superiores ca. 7,5 × 1,1 $\mathrm{cm}$; tépala inferior ca. 7,4 $\times 1,1 \mathrm{~cm}$; paraperigônio ausente; filetes 4 em comprimentos diferentes, anteras elípticas, ca. $6 \mathrm{~mm}$ compr.; ovário oboval a elítptico; estigma trífido. Fruto não visto.

Material examinado: BAHIA: Barreiras, divisa Bahia/ Goiás, 9.X.1981, f1., G. Hatschbach 44098 (MBM, typus). TOCANTINS: Goiatins, Kapey - União das Aldeias Krahò, 27.IX.2002, fl., A. Amaral-Santos 1776 (CEN); Miracema do Tocantins, estrada entre Lageado e Miracema do Tocantins, 0941'34'S, 48²3'39'W, 25.IX.1998, fl., G.F. Árbocz 6155(UB).

Habranthus conterminus é próxima morfologicamente a $H$. goianus Ravenna. Entre as características que diferenciam as duas espécies estão as flores crateriformes, tubo do hipanto 8,5-9 mm compr., perigônio até 7,5 cm compr., estigma trilobado em $H$. goianus e trífido em 
H. conterminus. A última característica também é utilizada para distinguir $H$. conterminus de $H$. sylvaticus Herb. Dutilh \& Oliveira (2013) referem $H$. conterminus na sinonímia de Z. sylvaticus Herb. O material-tipo de $H$. conterminus foi analisado e se trata sem dúvida de um exemplar do gênero Habranthus e uma espécie diferenciada das demais. Ocorre na Bahia e no Tocantins em mata de galeria e campo, em solo areno-argiloso, aos 200-240 m de altitude. Floresce nos meses de setembro e outubro.

\section{Habranthus datensis Ravenna, Onira 3(16): 58,} 1999. Fig. 1n-p

Bulbos globobos, 3,5-4 × 3-5 cm, colo 1,5$4,5 \mathrm{~cm}$ compr. Folhas verdes, lineares, ca. $8 \times 4 \mathrm{~cm}$, ápice agudo; nervuras ca. 14. Escapos $12-17(-22) \times$ $0,1-0,4 \mathrm{~cm}$; brácteas esverdeadas com base rosada, 2,5-3,5 cm compr; bractéolas ausentes; pedicelo ocre, 3-4,5 cm compr. Flores infundibuliformes, 5,5-7 cm compr., tubo do hipanto 2-5 mm compr.; tépalas brancas a rosa-claro, nervuras mais escuras no verticilo externo, oblanceoladas; verticilo externo com 14-19 nervuras principais, ápice obtuso a levemente emarginado, região papilar concentrada no ápice, fortemente oboval; tépala superior sem cintura, ca. $5,2 \times 1,2 \mathrm{~cm}$, tépalas laterais inferiores ca. 5,2 × 1,1-1,4 cm; verticilo interno com 10-13 nervuras principais, ápice arredondado a levemente emarginado; tépalas laterais superiores ca. $4,8 \times 1 \mathrm{~cm}$, tépala inferior ca. $5 \times 0,8 \mathrm{~cm}$; paraperigônio presente, formado por franjas de fímbrias digitiformes; filetes em 4 comprimentos diferentes, anteras oblongas, 8-12 mm compr.; ovário oboval; estigma trilobado. Fruto não visto.

Material selecionado: BAHIA: Rio de Contas, $13^{\circ} 32^{\prime} \mathrm{S}$, 41 ${ }^{\circ} 54^{\prime}$ 'W, 28.X.1988, fl., R.M. Harley et al. 25712 (SPF); Jacobina, Serra de Jacobina, XI.1986, fl., L.P. Queiroz et al. 1207 (HUEFS). MINAS GERAIS: Buenópolis,


24835 (SPF); Januária, 1500’60”S, 1457’22”W, 24.X.1997, fl., J.A.A. Lombardi 2073 (SPF); Paraopeba, Horto Florestal de Paraopeba, 30.X.1959, fl., E.P. Heringer 7253 (UB). SÃO PAULO: Piracicaba, ESALQ/ USP, ao lado da Avenida Independência, XII.1994, fl., P.H. Miyagi \& M.Y. Nakagomi 239(UEC). TOCANTINS: Paranã, próximo ao cruzamento, 3.X.2008, fl., A.C. Amaral \& G. Moreira 51 (CEN); São Salvador, Linha de Transmissão, Torre 144, 1254'41'S, 48 16'08'W, 12.XI. 2008, fl., B. Walter et al. 5834 (CEN).

Habranthus datensis é muito semelhante a $H$. robustus Herbert e $H$. botumirensis, principalmente em material herborizado. Dentre as características que separam estas espécies estão a presença de bractéolas, flores crateriformes, colo do bulbo até 7 cm compr. e folhas com até 20 nervuras principais em $H$. robustus e bulbos ovais, folhas com até 11 nervuras principais, ápice das tépalas externas mucronado e internas com 7-9 nervuras principais, em H. botumirimensis. Registrada para Bahia, Minas Gerais, São Paulo e Tocantins na caatinga, cerrado sensu stricto, cerrado de altitude e campos, em solos arenosos e afloramento de calcário, aos 500-750 m e $1150 \mathrm{~m}$ de altitude. Floresce em outubro a dezembro.

8. Habranthus gameleirensis Ravenna, Onira 3(16): 57-58, 1999.

Fig. 2a-c

Bulbos ovais, ca. $3 \mathrm{~cm}$ diâm., colo ca. 3,7 cm compr. Folhas ausentes durante a floração, não observadas. Escapos 18-25 × 0,1-0,4 cm; brácteas castanho-claras, 2,3-3,5 cm compr., com lobos de até ca. $8 \mathrm{~mm}$ compr.; bractéolas ausentes; pedicelo amarelo a verde-claro, 2,9-4,1 cm compr. Flores infundibuliformes, 6-7,2 cm compr.; tubo do hipanto 7-10 mm compr.; tépalas brancas a róseas, nervuras mais escuras no verticilo externo, oblanceoladas; verticilo externo com 14-16 nervuras principais, ápice levemente acuminado, região papilar em faixa longitudinal; tépala superior sem cintura, 5,6-6,6× $1,5 \mathrm{~cm}$, tépalas laterais inferiores 5,4-6,6 × 1,3-1,4 $\mathrm{cm}$; verticilo interno com ca. 11 nervuras principais, ápice obtuso a levemente cuspidado; tépalas laterais superiores 5,2-6,4 × 1,1 cm, tépala inferior 5,3-6,4 × 1,2 cm; paraperigônio ausente; filetes em 4 comprimentos diferentes, anteras oblongas, 2-5 mm compr;; ovário levemente oboval; estigma trilobado.

Fruto não visto.

Material examinado: TOCANTINS: Colinas, rio Gameleira, bulbo coletado em Cerrado, próximo a Colinas, 25.VII.1978, fl., M.J.P. Pires e M.R. Santos 16169 (INPA, Holotypus).

Habranthus gameleirensis é apontada por Ravenna (1999a) como diferentes das outras espécies do gênero, sendo muito difícil compará-la principalmente em relação às espécies brasileiras. Uma espécie que poderia ser comparada a $H$. gameleirensis seria $H$. robustus, mas apenas em relação ao comprimento da flor, que em $H$. gameleirensis é 6-7,2 cm e em H. robustus é 5,5-8 $\mathrm{cm}$. Ocorre no Tocantins no cerrado aos $200 \mathrm{~m} \mathrm{de}$ altitude. Floresce em julho.

\section{Habranthus goianus Ravenna, Plant Life 30:} 45, 1974

Fig. 2d

Bulbos ovais, 2,3-3 × 2,1-2,5 cm, colo ca. $3,5 \mathrm{~cm}$ compr. Folhas ausentes durante a floração, não observadas. Escapos 13-20 × 0,2-0,4 cm; 


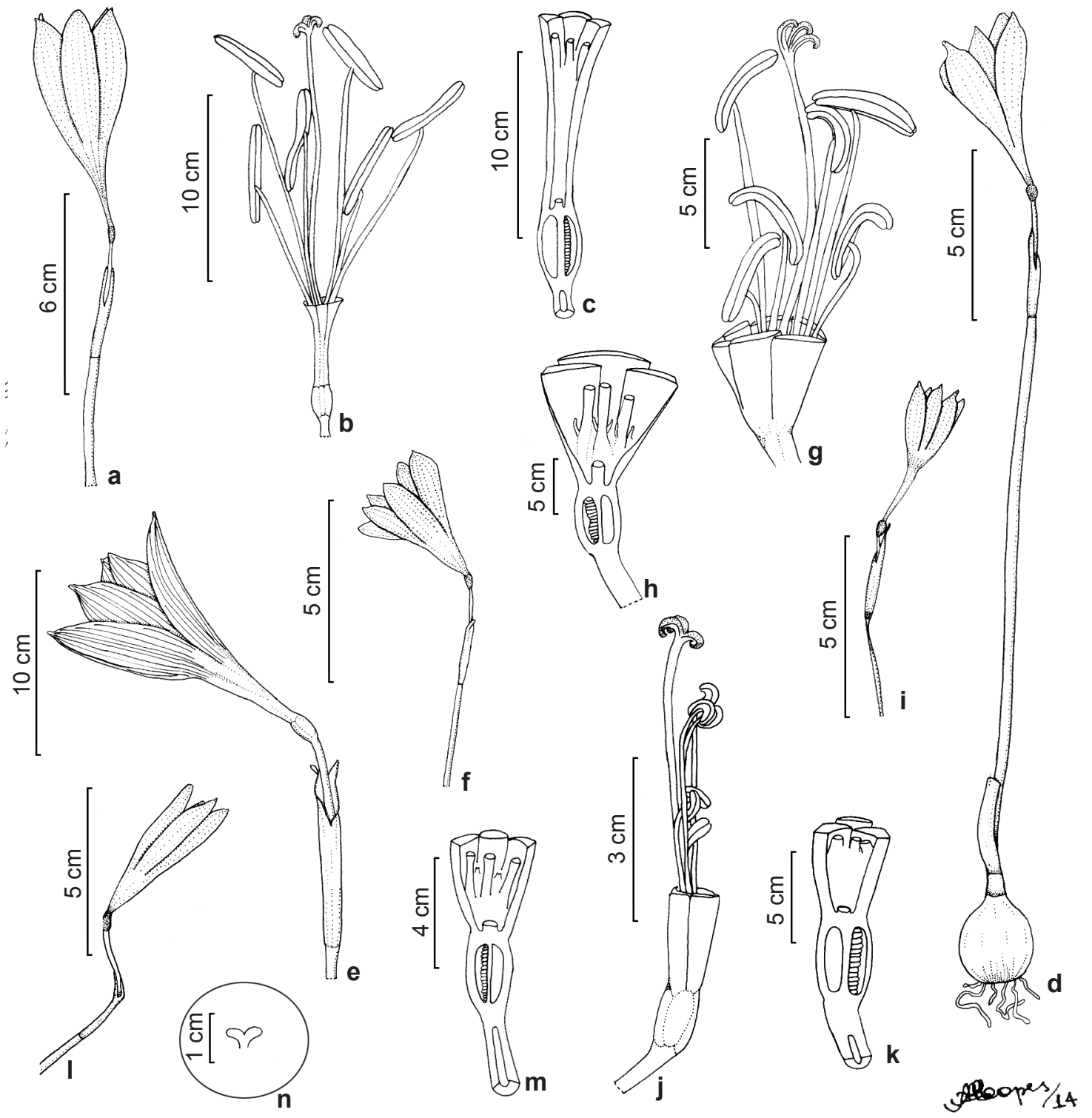

Figura 2 - a-b. Habranthus gameleirensis Ravenna - a. flor em vista lateral; b. flor, retirada as tépalas, evidenciando estames, estilete e estigma. c. flor em corte longitudinal (Pires \& Santos 16169). d. Habranthus goianus Ravenna, hábito (Prance \&Silva 58502). e. Habranthus gracilifolius Herb., flor em vista lateral (Trinta 1237). f-h. Habranthus irwinianus Ravenna - f.flor em vista lateral; g. flor, retirada as tépalas, evidenciando estames, estilete e estigma; h. flor em corte longitudinal, evidenciando paraperigônio com segmentos septiformes (Silva \& Ferreira 3158). i-k. Habranthus itaobinus Ravenna - i. hábito; j. flor, retirada as tépalas, evidenciando estames, estilete e estigma; k. flor em corte longitudinal, evidenciando paraperigônio com calosidades opostas à base dos filetes (Amaral 33). 1-n. Habranthus lacteus (S. Moore) Ravenna - 1. flor em vista lateral; $\mathrm{m}$. flor em corte longitudinal, evidenciando paraperigônio com calosidades opostas à base dos filetes; n. paraperigônio em detalhe (Mendonça et al. 2672). Ilustração de A. Amaral-Lopes.

Figure 2 - a-c. Habranthus gameleirensis Ravenna - a. flower in lateral view; b. flower, the tepals removed, showing stamens, style and stigma. c. flower in longitudinal section (Pires \& Santos 16169). d. Habranthus goianus Ravenna, habit (Prance \& Silva 58502). e. Habranthus gracilifolius Herb., flower in lateral view (Trinta 1237). f-h. Habranthus irwinianus Ravenna - f. flower in lateral view, g. flower, the tepals removed, showing stamens, style and stigma, h. flower in longitudinal section, showing paraperigônio with septiformes segments (Silva \& Ferreira 3158). i-k. Habranthus itaobinus Ravenna - i. habit; j. flower, the tepals removed, showing stamens, style and stigma; $\mathrm{k}$. flower in longitudinal section, showing paraperigônio callus with opposite threads of the base (Amaral 33). 1-n. Habranthus lacteus (S. Moore) Ravenna - 1. flower in lateral view; m. flower in longitudinal section, showing paraperigônio with opposite calluses based fillets; n. paraperigônio in detail (Mendonça et al. 2672). Illustration A. Amaral-Lopes. 
brácteas castanho-acinzentadas, 2,5-3,2 cm compr.; bractéolas ausentes; pedicelo verde, 3,3-4,2 cm compr. Flores crateriformes, 5,5-7,5 cm compr., tubo do hipanto 8,5-9 mm compr., tépalas roxas a violetas, oblanceoladas; nervuras do verticilo externo não observadas, ápice de apículo conspícuo, região papilar em faixa longitudinal; tépala superior sem cintura, 4,4-7 cm compr., largura não medida, tépalas laterais inferiores 4,6-7,1 cm compr., largura não medida, nervuras do verticilo interno não observadas, ápice acuminado; tépalas laterais superiores 4,4-7 cm compr., largura não medida; tépala inferior 4,3-6,8 cm compr., largura não medida; paraperigônio ausente; filetes em 4 comprimentos diferentes, anteras reniformes, 6-8 mm compr.; ovário levemente oboval; estigma trilobado. Fruto não visto.

Material examinado: BRASIL. GOIÁS: Nova Colinas, Rod. Belém-Brasília highway, $5 \mathrm{~km}$ North of Nova Colinas, 31.VII.1964, fl., G.T. Prance \& T. Silva 58502 (UB, Holotypus).

Habranthus goianus é caracterizada pelas flores crateriformes roxas a violetas, de 5,5-7,5 cm compr. e pela ausência de folhas na floração. É muito semelhante a $H$. sylvaticus por apresentar bulbos globosos, bractéolas ausentes, flores crateriformes roxas, filetes em 4 compr. diferentes e estigma trilobado. Entretanto, H. sylvaticus difere pelas folhas lineares, presentes na floração e pelo tubo do perigônio mais longo, de 1-2 cm compr. Ocorre em cerrado, aos 200-400 m de altitude. Floresce em julho.

10. Habranthus gracilifolius Herbert, Bot. Mag. 51: t. 2464. 1824 [1 Feb 1824]. Fig. 2e

Bulbos globosos, 1,5-1,7 × 1,5-1,7 cm, colo ca. 1,5 cm compr. Folhas verdes, lineares, ca. 14,5 × $0,3 \mathrm{~cm}$, ápice agudo; nervuras ca. 9. Escapos ca. 20,5 $\times 0,15-0,2 \mathrm{~cm}$; brácteas marrom-acinzentadas, 3-3,2 cm compr.; bractéolas ausentes; pedicelo verde, 4,5-5 cm compr. Flores crateriformes, 4-6 cm compr.; tubo do hipanto 3-4 mm compr.; tépalas rosa a lilases, oblanceoladas; verticilo externo com ca. 20 nervuras principais, ápice com apículo conspícuo, região papilar em faixa longitudinal; tépala superior com cintura, ca. $3,4 \times 0,5-0,6 \mathrm{~cm}$, tépalas laterais inferiores 4-5,5 × 0,5-0,7 cm; verticilo interno com ca. 8 nervuras principais, ápice acuminado; tépalas laterais superiores ca. $3,2 \times 0,6-0,7 \mathrm{~cm}$, tépala inferior 3,8-5,4 ×0,4 cm; paraperigônio ausente ou inconspícuo; filetes em 4 comprimentos diferentes, anteras reniformes, 6-9 mm compr.; ovário oboval; estigma trilobado. Fruto não visto.
Material examinado: PARANÁ: Palmas, Rodovia BR 280, 2655'42”'S, 51 94'20"W, X.2008, fl., R.S. Oliveira \& Peter de Camargo 121 (UEC). RIO GRANDE DO SUL: Santanta do Livramento, 28.I.1966, fl., Z.A. Trinta 1237 (HB).

Habranthus gracilifolius assemelha-se a H. irwinianus em função da presença de bulbos globosos, folhas presentes na antese, flores róseas a lilases com tépalas oblanceoladas, filetes em 4 comprimentos diferentes e estigma trilobado. Folhas filiformes, flores infundibuliformes e paraperigônio presente, formado por segmentos setiformes eretos são algumas das características presentes em $H$. irwinianus que a separam de $H$. gracilifolius. Para o estado do Paraná, Dutilh \& Oliveira (2013) citam apenas H. concinnus. No entanto, $H$. gracilifolius também está presente neste estado. Dutilh \& Oliveira (2013) consideram essa espécie como Z. gracilifolia. Entretanto pelo estudo do material a espécie é considerada como pertencente ao gênero Habranthus. As autoras ainda consideram $H$. gracilifolius var. boothianus, além da variedade tipo. No entanto, nenhuma variedade foi observada nesse trabalho. Essa espécie é semelhante a $H$. irwinianus, semelhança também relatada por Ravenna (1967) e Oliveira (2006). Ocorre em locais brejosos, aos 260-1100 m de altitude. Floresce nos meses de outubro e janeiro.

\section{Habranthus irwinianus Ravenna. Plant Life} 26(1): 97, 1970.

Fig. 2f-h

Bulbos globosos, 1,5-2,2 × 1-2,5 cm, colo 7-25 mm compr. Folhas verdes, com base vinácea, filiformes, ca. $15 \times 0,1 \mathrm{~cm}$, ápice agudo; nervuras ca. 10. Escapos (4,5-)6-15(-24) × 0,1-0,3 cm; brácteas vináceas, 1,7-3,3 cm compr.; bractéolas quando presentes filiformes; pedicelo verde-vináceos, 1,5$3,5(-5) \mathrm{cm}$ compr. Flores infundibuliformes, $3-5 \mathrm{~cm}$ compr.; tubo do hipanto 1,5-3(-4) mm compr.; tépalas róseas a lilases, oblanceoladas; verticilo externo com 15-20(-23) nervuras principais, ápice agudo, região papilar em faixa longitudinal, distribuindo-se por todo o ápice; tépala superior sem cintura, $2,3-3,9(-5,3) \times$ $0,5-1,2 \mathrm{~cm}$, tépalas laterais inferiores $2,5-4,2(-4,8) \times$ $(0,5-) 0,8-1,5 \mathrm{~cm}$; verticilo interno com 6-13 nervuras principais, ápice agudo; tépalas laterais superiores $2,1-3,6(-5) \times 0,3-0,7(-1,4) \mathrm{cm}$, tépala inferior 2,1-3,9 $(-5,4) \times 0,3-0,6(-1) \mathrm{cm}$; paraperigônio presente, formado por segmentos setiformes eretos, pareados e flanqueando os filetes na base; filetes em 4 comprimentos diferentes, anteras oblongas, 2-4 mm compr; ovário fortemente oboval; estigma trilobado. Fruto não visto. 
Material selecionado: BAHIA: Correntina, na casa do Sr. Zeca, no Bairro Sucuiú, 23.X.1995, fl., M.V. Martins et al. 267 (CEN). GOIÁS: Alto Paraíso, Vale da Lua, 14¹0'98”'S, 4747'48”'W, IX.1995, fl., T.S. Filgueiras \& R.C. Oliveira 3294 (IBGE, US, RB); Guarani, estrada de chão entre Guarani e Posse, $13^{\circ} 49^{\prime} 01^{\prime \prime}$, 46 31'48'W, 19.X.2001, fl., R.C. Mendonça et al. 4488 (IBGE, CEN, MO, ESA). MINAS GERAIS: Aiuruoca, Matutu, 10.X.2004, fl., R.C. Mota et al. 2507 (BHCB); Brumadinho, Serra da Rola Moça, 19.IX.1993, fl., E.L. Borba 46 (SPF); Caeté, Serra da Piedade, 10.X.2004, fl., R.S. Oliveira et al. 59 (SPF). Carmópolis de Minas, Estação Ecológica da Mata do Cedro, X.2005, fl., L. Echternacht et al. 1066 (BHCB); Catas Altas, Serra da Caraça, 1.XI.1997, fl., M.F. Vasconcelos \& P.H.C. Corgosinho (SPF); Conceição do Ibitipoca, XII. 2000, fl., F.R. Salimena (CESJ); Itabirito, Pico do Itabirito, 20.IX.1993, fl., W.A. Teixeira (SPF); Moeda, Serra da Moeda, Marinho da Serra/C1, 20²0'54'S, 4356'17'W, 15.IX.2006, fl., F.F. Carmo 165 (BHCB); Lima Duarte, Serra do Ibitipoca na baixada do Pião, 19.IX.1940, fl., G. Mendes Magalhães 413 (HB); Ouro Branco, Serra do Ouro Branco, 14.VII.2002, fl., C.C. Paula et al. 191 (SPF); Ouro Preto, Serra de Capanema/C1, 20¹2'35'S, 4334'27'W, 11.IX.2007, fl., F.F. Carmo 1048 (BHCB); Rio Preto, Ribeirão Santana, Usina Hidrelétrica de H. de Melo, I.1996, fl., F.R. Salimena et al. (CESJ);Sacramento, Parque Nacional da Serra da Canastra, estrada São Roque de MinasSacramento, a 46km da portaria de São Roque de Minas, 7.XII.2002, fl., R. Mello-Silva et al. 1962 (UEC); São Roque de Minas, Serra da Canastra, 21.II.1994, fl., J.N. Nakajima \& R. Romero 153 (SPF); Serra do Espinhaço, I.1971, fl., H.S. Irwin et al. 28958 (UB). PERNAMBUCO: Cruzeiro do Nordeste, II.1997, fl., A.M. Miranda \& Gomes 2608 (HUEFS). SÃO PAULO: Botucatu, ao longo da estrada São Manuel-Piracicaba, $22^{\circ} 45^{\prime}$ S, $48^{\circ} 25^{\prime}$ 'W, 22.VIII.1974, fl., G. Gottsberger \& Campos 16-22874 (UB).

Habranthus irwinianus assemelhase a $H$. gracilifolius pela presença de bulbos globosos, folhas presentes na antese, flores róseas a lilases com tépalas oblanceoladas, filetes em 4 comprimentos diferentes e estigma trilobado. Folhas lineares, com margens revolutas, flores crateriformes e paraperigônio ausente são algumas das características presentes em $H$. gracilifolius que a separam de $H$. irwinianus. Ocorre na Bahia, Goiás, Minas Gerais, Pernambuco e São Paulo, em formações de campo limpo e cerrado rupestre, principalmente em solos areno-pedregosos, aos 500-700 e 1100-1500 m de altitude. Floresce de julho a fevereiro. Classificada como vulnerável (Livro Vermelho da Flora do Brasil 2013).

12. Habranthus itaobinus Ravenna. Onira 3(16): 56, 1999.

Fig. 2i-k

Bulbos globosos, 1,5-3 × 1,5-2,5 cm, colo 1,5-3,5 cm compr. Folhas verdes, lineares, ca. $8 \times$
$0,1 \mathrm{~cm}$, ápice agudo; nervuras 8-12. Escapos 8-23 $\times 0,1-0,3-0,6) \mathrm{cm}$; brácteas rosadas, $2-3 \mathrm{~cm}$ compr.; bractéolas ausentes; pedicelo verde a marrom, 2-5 cm compr. Flores crateriformes, 3-5 cm compr.; tubo do hipanto 3-6 mm compr.; tépalas brancas a róseas com base esverdeada e ápice com coloração mais evidente, oblanceoladas; verticilo externo com 9-16 nervuras principais, ápice mucronado, região papilar oboval; tépala superior sem cintura, $2,6-3,9 \times 0,7-0,8 \mathrm{~cm}$, tépalas laterais inferiores não observadas; verticilo interno com 7-12 nervuras principais, ápice agudo; tépalas laterais superiores $2,5-4 \times 0,5-0,6 \mathrm{~cm}$, tépala inferior 2,4-3,9 × 0,5-0,6 $\mathrm{cm}$; paraperigônio presente, formado por calosidades opostas à base dos filetes; filetes em 2 comprimentos diferentes,anteras oblongas, 3-6 mm compr.; ovário oboval; estigma trilobado. Fruto não visto.

Material selecionado: BAHIA: Água Quente, $13^{\circ} 30^{\prime} \mathrm{S}$, 4159”'W, 1.XII.1988, fl., M. Fothergill 58 (SPF); Feira de Santana, Campus da HUEFS, $12^{\circ} 15^{\prime} \mathrm{S}, 38^{\circ} 58^{\prime} \mathrm{W}$, atrás do LABIO, no fundo do LAMOL, $12^{\circ} 15^{\prime} \mathrm{S}, 38^{\circ} 58^{\prime} \mathrm{W}$, 25.XI.2004, fl., M.J.G. Andrade \& M. Vanilda 575 (HUEFS); Itatim, Morro da Tocas, $12^{\circ} 43^{\prime} \mathrm{S}, 39^{\circ} 42^{\prime} \mathrm{W}$, IX.1996, fl., F. França et al. 1839 (HUEFS); Morro do Chapéu, Estrada do Feijão, 28.XII.1980, fl., A. Furlan et al. 262 (HUEFS,SPF); Rio de Contas, arredores de Marcolino Moura, 1337'42”S, 4140'43”W, 1.XI.2004, fl., R.M. Harley \& A.M. Giullietti 55200 (HUEFS); Urandi, 25.IX.1997, R. Mello-Silva 1411 (SPF). CEARÁ: Crato, Serra de Araripe, 2.I.1982, fl., A.L. Peixoto \& O.L. Peixoto 1652 (UEC). GOIÁS: Campos Belos, Fazenda Mundo Novo, próximo ao povoado de Pouso Alto, $12^{\circ} 58^{\prime} 43^{\prime}$ 'S, 46²9'53”W, 1.XI.2000, fl., M. Aparecida da Silva et al. 4631 (IBGE, FLAS, SGO, SP, CEN); Flores, Fazenda Capim Puba, parte da antiga fazenda Cachoeirama, 14¹6'42”S, 4659'21'W, X.2004, fl., R.C. Mendonça et al. 5783 (IBGE). MATO GROSSO: Cuiabá, $46 \mathrm{Km}$ da rodovia BR 158 entre Xavantina e Água Boa, 08.X.1988, fl., M.G.L. Wanderley \& R. Kral 1242 (CH); Santo Antônio de Leverger, estrada da ponta do morro, próximo a Fazenda Tapera, $15^{\circ} 45^{\prime} 11^{\prime \prime}$ 'S, 5604'17''W, X.1978, fl., A. Macedo et al. 938 (UEC). MINAS GERAIS: GrãoMogol, 11.XI.2003, fl., R.S. Oliveira \& E.H.P. Andrade 47 (SPF); Itaobim, 13.IX.1984, fl., G. Hatschbach 48134 (MBM, Holotypus); Januária, 1500'60”'S, 44²4’35”'W, 24.X.1994, fl., J.A.A. Lombardi 2071 (SPF); Jaiba, 15¹2’37'S, 4351'33”W, 20.X.2001, fl., J.A.A. Lombardi et al. 4474 (SPF); Pedra Azul, XI.1958, fl., G.M. Magalhães (HB); Salinas, arredores da cidade, na estrada norte para Taiobeiras, $16^{\circ} 10^{\prime} \mathrm{S}, 42^{\circ} 18^{\prime} \mathrm{W}, 16 . \mathrm{X} .1988$, fl., R.M. Harley et al. 25145 (UEC). PERNAMBUCO: Bezerros, Fazenda Antônio Bezerra, 16.III.2006, fl., A. Alves-Araújo et al. 71 (HUEFS).

Habranthus itaobinus apresenta ampla variação morfológica já relatada por outros autores (Ravenna 1999a; Oliveira 2006). Essa 
variação morfológica parece não estar relacionada à fatores ambientais, como já foi relatada para Hippeastrum (Dutilh 1996), e sim à plasticidade genética dos indivíduos, ou seja, a ocorrência de cruzamento de $H$. itaobinus com indivíduos de outras espécies. Oliveira (2006) relata que os indivíduos de $H$. itaobinus, quando herborizados, são muito confundidos com $Z$. cearensis Herb. e Z. franciscana Backer principalmente em função das suas flores, mas não cita quais as características responsáveis pela confusão. Também relata que estas espécies apresentam sobreposição de distribuição geográfica. Neste caso, seria necessária uma maior investigação para o melhor esclarecimento e delimitação dessas espécies. Ocorre na Bahia, Ceará, Goiás, Mato Grosso, Minas Gerais e Pernambuco, na caatinga, cerrado campo rupestre, campos e brejos temporários, em solos arenosos, areno-argilosos e afloramento de calcário, a 200-1000 m de altitude. Floresce nos meses de setembro a janeiro.

13. Habranthus lacteus (S. Moore) Ravenna. Onira 1(8): 56. 1988.

Fig. 21-n

Bulbos ovais, ca. 1,6 × 1,4 cm, colo ca. 7 $\mathrm{mm}$ compr. Folhas verdes, filiformes, 1,3-1,7 $\times$ 0,1-1,2 cm, ápice agudo; nervuras ca. 5. Escapos 20-32 × 0,1-0,2 cm; brácteas castanhas, 1,7-2,3 cm compr.; bractéolas ausentes; pedicelo verde-claro, 3-3,5 cm compr. Flores infundibuliformes, 4,5-6 cm compr.; tubo do hipanto 3-4 cm compr.; tépalas róseas a brancas, oblanceoladas; verticilo externo com 12-16 nervuras principais, ápice agudo, região papilar não observada; tépala superior sem cintura, $4,2-5,6 \times 0,6-1,3 \mathrm{~cm}$, tépalas laterais inferiores 4,1-5,5 × 0,6-1,3 cm; verticilo interno com 9-11 nervuras principais, ápice agudo; tépalas laterais superiores 3,8-5 x 0,4-0,6 cm, tépala inferior 3,84,8 $\times 0,4-0,6 \mathrm{~cm}$; paraperigônio presente, formado por segmentos denteados, pareados e entre a base dos filetes; filetes em 2 comprimentos diferentes, anteras reniformes, 2-6 mm compr.; ovário elíptico; estigma trilobado. Fruto não visto.

Material examinado: GOIÁS: Alto Paraíso, Parque Nacional Chapada dos Veadeiros, 1409'43"S, 47050'02"W, 10.IX.1996, fl., R.C. Mendonça et al. 2672 (UEC). MINAS GERAIS: Verdelândia, km 86 da estrada Jaíba-Verdelândia, 15²5'54"S, 4337'10”W, 20.X.2001, fl., J.A.A. Lombardi et al. 4476 (SPF).

Habranthus lacteus pode ser confundida com $H$. pantanalensis pelas folhas presentes na antese, escapo verde-claro, brácteas castanhas, flores infundibuliformes, estigma trilobado e ovário elíptico. Diferem por $H$. pantanalensis apresentar bulbos subglobosos a globosos, folhas lineares com 12 nervuras principais e estames em 4 comprimentos diferentes. Dutilh \& Oliveira (2013) referem $H$. lacteus na sinonímia de $Z$. lactea S. Moore. O material-tipo de H. lacteus foi analisado e se trata sem dúvida de uma boa espécie do gênero Habranthus. Ocorre em Goiás e Minas Gerais, no cerrado, carrasco, em solo arenoso e afloramentos de quartzo, aos 490-1200 $\mathrm{m}$ de altitude. Floresce em setembro e outubro.

14. Habranthus lucidus R.S.Oliveira. Kew Bulletin 64: 537-541, 2009.

Bulbos globoso, 2,2-3,4 × 1,9-2,2 cm, colo 1,7-3,1 cm compr. Folhas verdes, lineares, ca. $6 \times 0,3 \mathrm{~cm}$, ápice agudo; nervuras 7-9. Escapos $11-14 \times 0,2-0,4 \mathrm{~cm}$; brácteas rosadas, 2-3 cm compr.; bractéolas ausentes; pedicelo verde, 2,7-3,6 cm compr. Flores infundibuliformes, 4-5,2 cm compr.; tubo do hipanto 2-5 $\mathrm{mm}$ compr.; tépalas róseas com base esverdeada, nervuras mais escuras, oblanceoladas; verticilo externo com 15-19 nervuras principais, ápice cuspidado, região papilar oval; tépala superior sem cintura, 2,7-4,5 ×0,4-1 cm, tépalas laterais inferiores 1,5-2 cm; verticilo interno com 7-9 nervuras principais, ápice arredondado a levemente cuspidado; tépalas laterais superiores $3,8-4,4 \times 0,8-1 \mathrm{~cm}$, tépala inferior $3,8-4,4 \times$ 0,8-1 cm; paraperigônio presente, formado por franjas de fimbrias digitadas; filetes em 2 comprimentos diferentes, anteras oblongas, 4-5 mm compr.; ovário oboval; estigma trilobado. Fruto não visto.

Material examinado: BAHIA: Jussiape, Fazenda Veredas, 1334'09'S, 41³6'27'W, XI.1996, fl., H.P. Bautista et al. 4532 (HUEFS); Rio de Contas, arredores da cidade, na estrada para o Pico das Almas, $13^{\circ} 35^{\prime}$ S, 41ํㅇ' 'W, 960 m, 28.X.1988, fl., R.M. Harley et al. 25711 (SPF, Holotypus).

Habranthus lucidus é muito semelhante a $H$. datensis. Tal semelhança também já foi relatada por Oliveira \& Sano (2009). Habranthus datensis difere de H. lucidus por apresentar folhas com ca. de 14 nervuras principais e tépalas internas inferiores com 7-9 nervuras principais, ápice das tépalas externas obtuso a levemente cuspidado e nas internas arredondado a levemente emarginado e filetes em 4 comprimentos diferentes. Ocorre na Bahia. Floresce em outubro e novembro. Foi classificada como criticamente em perigo (Oliveira \& Sano 2009). 
15. Habranthus maranensis Ravenna, Plant Life 38: 1982.

Fig. 3d-f

Bulbos globosos, 2,3-3,2 × 2-3,5 cm, colo 1-3 cm compr. Folhas ausentes durante a floração, não observadas. Escapos 10-22 × 0,2-0,4 cm; brácteas rosadas, base verde, 2,2-3,5 cm compr., com lobos ca. 1,2 cm compr.; bractéolas ausentes; pedicelo verde-claro, 2,5-6 cm compr. Flores infundibuliformes, 5-8,5 cm compr.; tubo do hipanto 1-2,2 cm compr.; tépalas rosadas, obovais a oblanceoladas; verticilo externo $12-18$ nervuras principais, ápice acuminado; tépala superior sem cintura, 6-7,5 × 1-2 cm, tépalas laterais inferiores 6-8 × 1-2 cm; verticilo interno 11-13 nervuras principais, ápice mucronulado; tépalas laterais superiores $5,6-7,7 \times 1-1,5 \mathrm{~cm}$, tépala inferior 5,5-7,8 × 1-1,3 cm; paraperigônio ausente; filetes em 4 comprimentos diferentes, anteras elípticas, 3-10 mm compr.; ovário oboval a elíptico; estigma trilobado. Fruto não visto.

Material examinado: MARANHÃO: Carolina, estrada Carolina-balsa Babaçulândia km 11, marcados a partir da Igreja São Francisco de Assis, bairro Brejinho, 07¹5'14”S, 47³2'04”'W, 6.IX.2008, fl., G. PereiraSilva et al. 13775 (CEN); Caxias, aproximadamente 40 km de Caxias, BR 135, km 512, 20.X.1980, fl., D.C. Daly D-695 (INPA, NY, isotypus).

Habranthus maranensis caracteriza-se pelas flores infundibuliformes, tépalas rosadas, paraperigônio ausente e estigma trilobado. É morfologicamente semelhante a $H$. sylvaticus, que se distingue de $H$. maranensis pela presença de folhas durante a floração, flores crateriformes, púrpuras, paraperigônio presente, formado por segmentos em forma de gancho. É também próxima a $H$. goianus, que pode ser distinguida de H. maranensis pelas flores crateriformes, tubo do perigônio de 8,5-9 $\mathrm{mm}$ e tépalas oblanceoladas. A lista de espécies da Flora do Brasil cita $H$. maranensis, presente no estado do Maranhão, na sinonímia de Z. sylvatica (Mart.) Baker. O material-tipo de $H$. maranensis foi analisado e constatado que se trata de uma espécie do gênero Habranthus. Ocorre em cerrado, principalmente em áreas de campo e solo arenoso, aos $180 \mathrm{~m}$ de altitude. Floresce nos meses de setembro e outubro.

16. Habranthus minor Ravenna, Onira 9(2): 13. 2003.

Bulbos globosos, $1,7 \times 1,8 \mathrm{~cm}$, colo $1,2-1,5$ $\mathrm{cm}$ compr. Folhas verdes, filiformes, ca. $11 \times$ $0,1 \mathrm{~cm}$, ápice fortemente agudo; nervuras ca. 6 . Escapos 7-8,5 × 0,1-0,2 cm; brácteas verdes com ápice vináceo, 1,7-1,9 cm compr.; bractéolas ausentes; pedicelo verde-claro, 1,8-2,5 cm compr. Flores infundibuliformes, 2,5-3,2 cm compr.; tubo do hipanto ca. $3 \mathrm{~mm}$ compr.; tépalas lilases, oblanceoladas; verticilo externo com ca. 9 nervuras principais, ápice agudo, região papilar não observada; tépala superior sem cintura, ca. 2,9 $\times$ $0,4 \mathrm{~cm}$, tépalas laterais inferiores ca. 2,8-2,9 x 0,3 $\mathrm{cm}$; verticilo interno com ca. 5 nervuras principais, ápice agudo; tépalas laterais superiores ca. 2,7 × 0,2 $\mathrm{cm}$, tépala inferior ca. $2,8 \times 0,2 \mathrm{~cm}$; paraperigônio ausente; filetes em 4 comprimentos diferentes, anteras elípticas, 3-4 mm compr.; ovário globoso; estigma trilobado. Fruto não visto.

Material examinado: TOCANTINS: Paranã, rio Lajes, 12॰36'58”, 4753'01', 12.XI.1991, fl., G. Hatschbach et al. 56089 (MBM, typus).

Habranthus minor é a espécie que apresenta os menores indivíduos do gênero. Ravenna (2003) compara a espécie com $H$. coeruleus, $H$. concinnus, H. tubispathus e $H$. variabilis por também serem consideradas espécies de hábito reduzido. Essas espécies diferem de $H$. minor por apresentar flores lilases em $H$. concinnus, flores roxas em $H$. coeruleus, amplo perigônio infundibiliforme em $H$. variabilis e perigônio amarelo ou rosa, com tépalas mais largas em H. tubispathus. Habranthus minor pode ainda ser confundida com H. itaobinus. Entre as características que diferem as duas espécies estão as folhas lineares com 8-12 nervuras principais, escapo de até $23 \mathrm{~cm}$ compr., flores crateriformes, paraperigônio presente, formado por calosidades opostas a base dos filetes, presentes em $H$. itaobinus. Ocorre no Tocantins em cerrado, aos $270 \mathrm{~m}$ de altitude. Floresce no mês de novembro.

17. Habranthus pantanalensis Ravenna, Onira 3(16): 59, 1999.

Fig. 3g-j

Bulbos subglobosos a globosos, 1,5-2 $\times$ 1,8-2,2 cm, colo 1-3 cm compr. Folhas verdes, lineares, ca. $3 \times 0,3 \mathrm{~cm}$ compr., ápice agudo; nervuras ca. 12. Escapos 6-13,5 × 0,3-0,4 cm; brácteas castanhas, 1,8-1,9 cm compr.; bractéolas não observadas; pedicelo verde-escuro, 1,5-1,8 $\mathrm{cm}$ compr. Flores infundibuliformes, ca. 3,5 cm compr.; tubo do hipanto 3-4 cm compr.; tépalas brancas a róseas, oblanceoladas; verticilo externo 10-11 nervuras principais, ápice acuminado, região papilar não observada; tépala superior sem cintura, 4,5-6,5 × 2-2,2 cm, tépalas laterais inferiores 4,3-6,5 × 2-2,3 cm; verticilo interno com 7-8 nervuras principais, ápice acuminado; tépalas laterais superiores 4,2-6,5 × 2-2,2 cm, 

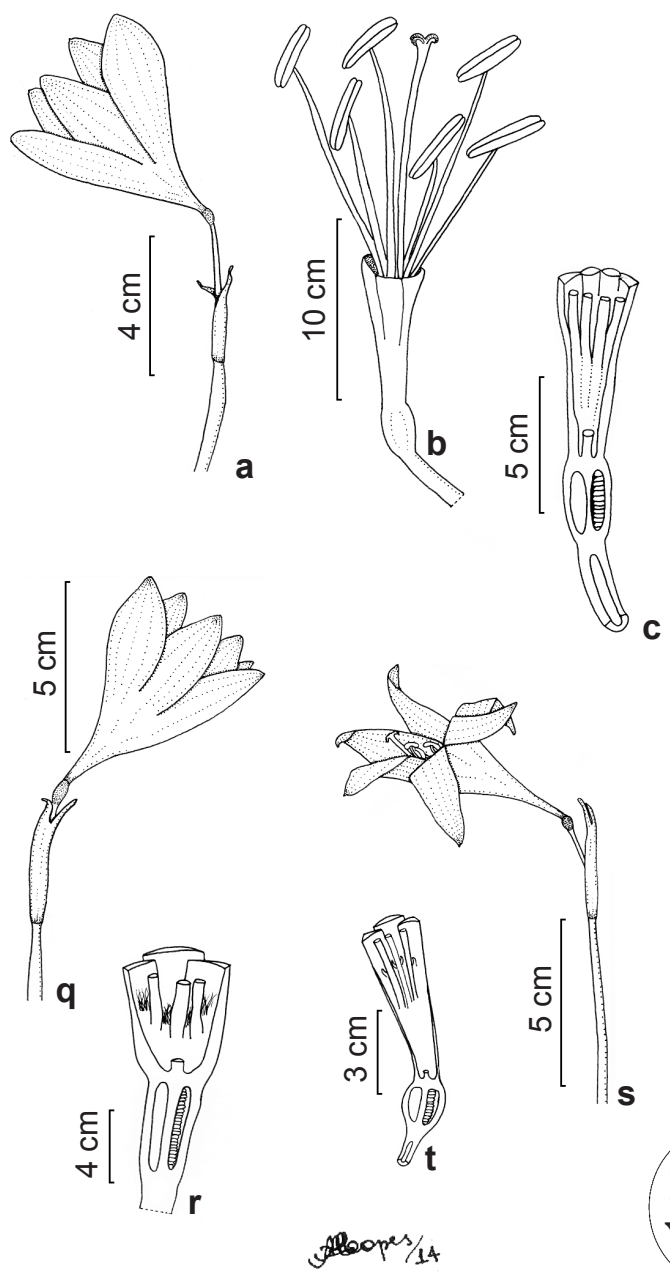

C
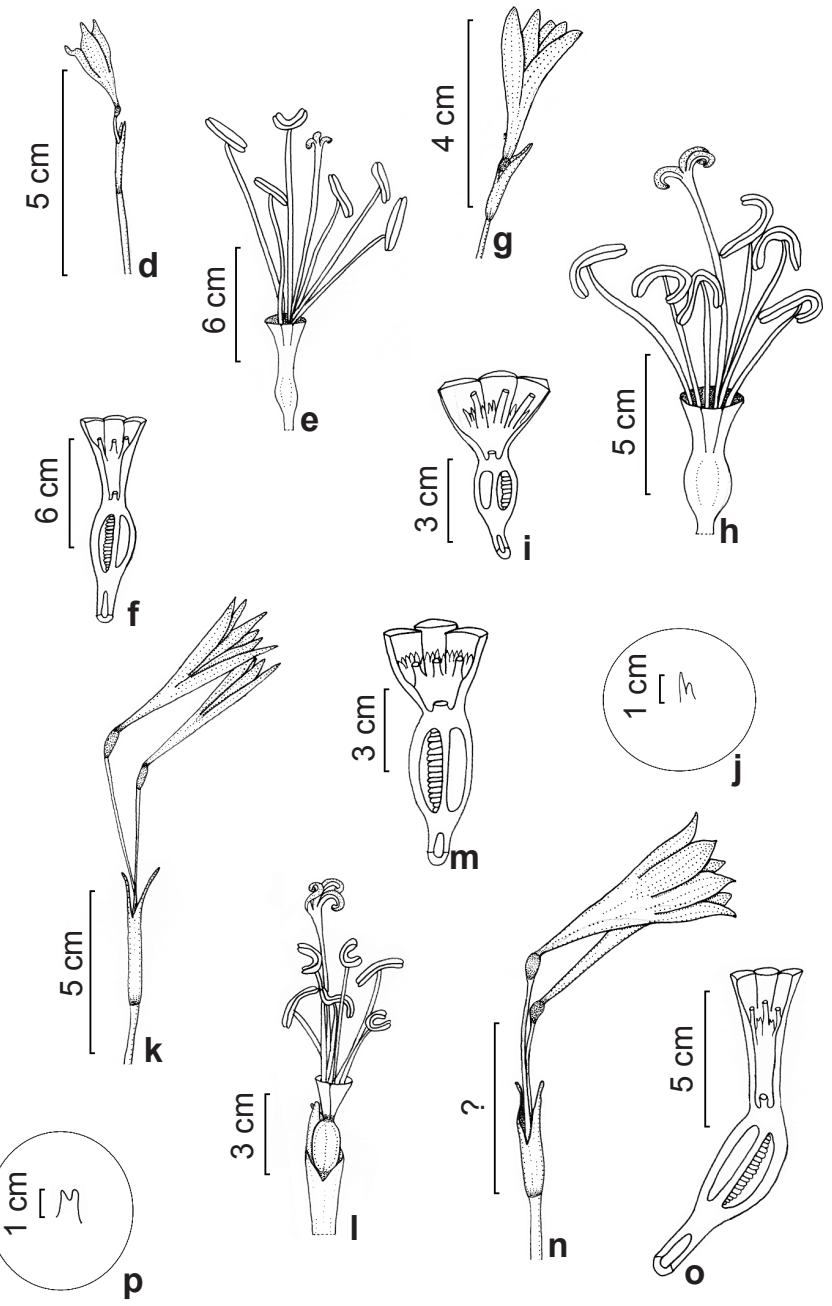

Figura 3 - a-c. Habranthus maranensis Ravenna - a. hábito; b. flor, retirada as tépalas, evidenciando estames, estilete e estigma; c. flor em corte longitudinal (Pereira-Silva 13775). d-f. Habranthus minor Ravenna - d. hábito; e. flor, retirada as tépalas, evidenciando estames, estilete e estigma; f. flor em corte longitudinal (Hatschbach et al. 56089). g-j. Habranthus pantanalensis Ravenna - g. hábito; h. flor, retirada as tépalas, evidenciando estames, estilete e estigma; i. flor em corte longitudinal, evidenciando paraperigônio com segmentos septiformes; j. paraperigônio em detalhe (Ramos et al. 08). k-m. Habranthus pedunculosus Herb. - k. flor em vista lateral; 1. flor, retirada as tépalas, evidenciando estames, estilete e estigma; m. flor em corte longitudinal, evidenciando paraperigônio com segmentos em forma de ganchos (Pabst \& Pereira 6611/6785). n-p. Habranthus robustus Herb. - n. flor em vista lateral; o. flor em corte longitudinal, evidenciando paraperigônio com segmentos filiformes; p. paraperigônio em detalhe (Guarino 1034). q-r. Habranthus ruber Ravenna-q. flor em vista lateral; r. flor em corte longitudinal, evidenciando paraperigônio com segmentos septiformes (Pabst7294). s-t. Habranthus sylvaticus (Martius ex Schultes) Herb. - s. Hábito; t. flor em corte longitudinal, evidenciando paraperigônio com segmentos em forma de ganchos (Cavalcanti 3361). Ilustração de A. Amaral-Lopes.

Figure 3 - a-c. Habranthus maranensis Ravenna - a. habit; b. flower, the tepals removed, showing stamens, style and stigma; c. Flower in longitudinal section (Pereira-Smith 13775). d-f. Habranthus minor Ravenna - d. habit; e. flower, the tepals removed, showing stamens, style and stigma; f. Flower in longitudinal section (Hatschbach et al. 56089). g-j. Habranthus pantanalensis Ravenna - g. habit; h. flower, the tepals removed, showing stamens, style and stigma; i. flower in longitudinal section, showing paraperigônio with septiformes segments; j. paraperigônio in detail (Ramos et al. 08). k-m. Habranthus pedunculosus Herb. - k. flower in lateral view; 1. flower, the tepals removed, showing stamens, style and stigma; $\mathrm{m}$. Flower in longitudinal section, showing paraperigônio with hooks shaped segments (Pereira \& Pabst 6611/6785). n-p. Habranthus robustus Herb. -n. flower in lateral view; o. flower in longitudinal section, showing paraperigônio with filiform segments; p. paraperigônio in detail (Guarino 1034). q-r. Habranthus ruber Ravenna - q. flower in lateral view; r. flower in longitudinal section, showing paraperigônio with septiformes segments (Pabst7294). s-t. Habranthus sylvaticus Herb. - s. habit; t. flower in longitudinal section, showing paraperigônio with hooks shaped segments (Cavalcanti 3361). Illustration A. Amaral-Lopes. 
tépala inferior 4,2-6,5 × 1,8-2,2 cm; paraperigônio presente, formado por segmentos setiformes, pareados e flanqueando os filetes na base; filetes em 4 comprimentos diferentes, anteras reniformes, 5-6 mm compr.; ovário elíptico; estigma trilobado. Fruto não visto.

Material selecionado: MATO GROSSO: Praia Grande, Várzea Grande, IX.1993, fl., A. Macedo et al. 3376 (UB). MATO GROSSO DO SUL: Corumbá, Nabileque, Faz. Acurí-ZAL, 19.X.1987, fl., A. Pott et al. 3633 (MBM, tуриs).

Habranthus pantanalensis pode ser confundida com H. lacteus em função da presença de flores infundibuliformes, róseas a alvas, $3-4 \mathrm{~cm}$ compr., tépalas oblanceoladas, estigma trilobado e ovário elíptico. Diferem por H. lacteus apresentar bulbos ovais, folhas filiformes, com cerca de 5 nervuras principais e estames em 2 comprimentos diferentes. Registrada para Mato Grosso e Mato Grosso do Sul em locais pouco alagáveis, em solo calcimórfico, aos $90 \mathrm{~m}$ de altitude. Floresce nos meses de setembro e outubro.

18. Habranthus pedunculosus Herbert, Amaryllidaceae 161. t. 26. f. 3. 1837. Fig. 3k-m

Bulbos ovais, 1,5-2 × 1,3-1,5 cm, colo 1,3-6,5 cm compr. Folhas verdes, lineares, ca. 11 $\times 0,1 \mathrm{~cm}$, ápice agudo; nervuras ca. 7. Escapos ca. $34,5 \times 0,1 \mathrm{~cm}$; brácteas castanho-rosadas, ca. 2 $\mathrm{cm}$ compr.; bractéolas filiformes; pedicelo verdeclaro, 2-7 cm compr. Flores infundibuliformes, ca. 5-6,5 cm compr.; tubo do hipanto ca. $5 \mathrm{~mm}$ compr.; tépalas brancas, oblanceoladas; verticilo externo com 11-15 nervuras principais, ápice atenuado, região papilar em faixa longitudinal; tépala superior sem cintura, ca. $4,5 \times 0,3 \mathrm{~cm}$, tépalas laterais inferiores 4,2-4,3 $\times 0,3 \mathrm{~cm}$ compr.; verticilo interno com 9-10 nervuras principais,ápice agudo; tépalas laterais superiores $4,2-4,4 \times 0,3 \mathrm{~cm}$, tépala inferior ca. $4 \times 3 \mathrm{~mm}$; paraperigônio presente, formado por segmentos em forma de ganchos, pareados e flanqueando os filetes na base; filetes em 2 comprimentos diferentes, anteras oblongas, 7-8 mm compr; ovário oblongo a elíptico; estigma trífido. Fruto não visto.

Material examinado: RIO GRANDE DO SUL: Passo do Ricardo, 4.XI.1961, fl., G. Pabst 6611 \& Pereira 6785 (HB); Osório, Fazenda do Arroio, I.1958, fl., Rambo 63639 (PACA).

Habranthus pedunculosus é caracterizado por flores infundibuliformes, alvas, 5-6,5 cm compr., paraperigônio formado por segmentos em forma de ganchos e estigma trífido. Em alguns casos, os espécimes de $H$. pedunculosus podem apresentar inflorescências com até quatro flores. Assemelha-se a H. estensis, espécie citada para o Uruguai, pelas folhas lineares, pelas inflorescências com até duas flores e ovários obovais. Habranthus estensis difere por apresentar bulbos subglobosos, ausência de folhas durante a floração e escapos com até $20 \mathrm{~cm}$ compr. Ocorre no Rio Grande do Sul, nos Pampas, em solos arenosos, aos $20 \mathrm{~m}$ de altitude. Floresce no mês de novembro e janeiro.

19. Habranthus robustus Herbert, Amaryllidaceae 166, 1837.

Fig. 3n-p

Bulbos globosos, 1,5-4,5 × 1-3 cm, colo 2-7 cm compr. Folhas verdes, lineares, levemente canaliculadas, ca. $20 \times 0,4-0,5 \mathrm{~cm}$, ápice agudo; nervuras 12-20. Escapos (11,5-)16-19(-27) $\times$ $0,3-0,6 \mathrm{~cm}$; brácteas rosadas, $3-4 \mathrm{~cm}$ compr.; bractéolas filiformes; pedicelo verde-claro, 2,5-4,5 cm compr. Flores crateriformes, 5,5-8 cm compr.; tubo do hipanto, 4-5 mm compr.; tépalas lilases, base esverdeada, obovais a oblanceoladas; verticilo externo com ca. 24-nervuras principais, ápice com apículo conspícuo, região papilar em faixa longitudinal com base em forma de semicírculo; tépala superior sem cintura, 5,2-7,2 × 1,2-1,4 cm, tépalas laterais inferiores $6,2-7,5 \times 1,5-1,7 \mathrm{~cm}$; verticilo interno com ca. 13 nervuras principais, ápice levemente apiculado; tépalas laterais superiores $6,5-7,2 \times 1,7-2,5 \mathrm{~cm}$, tépala inferior 5,2-7,2 × 1,1-1,8 cm; paraperigônio presente, formado por segmentos filiformes, flanqueando os filetes na base; filetes em 4 comprimentos diferentes, anteras reniformes, 3-6 mm compr.; ovário oblongo a elíptico; estigma trilobado. Fruto não visto.

Material examinado: RIO GRANDE DO SUL: Caçapava do Sul, Pedra do Segredo, XII.1994, fl., J.R. Stehmann et al. 1590 (UEC); Torres, XII.1993, fl., J.R. Stehmann et al. (UEC) . SANTA CATARINA: Celso Ramos, cerca de $3 \mathrm{~km}$ de Celso Ramos, 27⒋ $1^{\prime} 41^{\prime \prime} \mathrm{S}$, 5109'09"O, 18.IV.2006, fl., E.S.G. Guarino et al. 1034 (CEN); Florianópolis, 6.II.1964, fl., J.C. Sacco 1826 (HB); São Bento do Sul, margem da estrada do fundão, fl., 5.XII.2000, E. Gonçalves \& H. Lorenzi 625 (UB). SÃO PAULO: São Paulo, Cidade Universitária, Jardim do Departamento de Botânica, 30.XI.2005, fl., R.S. Oliveira 104 (SPF); Itapecerica, Paiol do Meio, 19.IX.1940, fl., A. Gerht (SPF).

Habranthus robustus é caracterizada por flores crateriformes, tépalas lilases, paraperigônio formado por segmentos filiformes, filetes em 4 comprimentos diferentes e estigma trilobado. 
Habranthus robustus está presente nos estados de São Paulo, Santa Catarina e Goiás. É frequentemente confundida por não estudiosos da família com espécies de Hippeastrum, em função da presença das longas flores, medindo 5-8 cm compr. Dutilh \& Oliveira (2013) referem $H$. robustus na sinonímia de Z. robusta Baker. O material-tipo de H. robustus foi analisado e foi constatado que se trata de um exemplar de Habranthus. Ocorre em áreas antropizadas, aos 20-850 m de altitude. Floresce em fevereiro, abril, novembro e dezembro.

20. Habranthus ruber Ravenna, Plant Life 26(1): 94, fig. 24, 1970.

Fig. 3q-r

Bulbos ovais, 2-3 × 1,5-2 cm, colo 2,5-7,5 cm compr. Folhas ausentes durante a floração. Escapos ca. $3,9 \times 0,4 \mathrm{~cm}$; brácteas verdeavermelhadas, 2,8-3,3 cm compr.; bractéolas filiformes; pedicelo verde, 3,2-6,2 cm compr. Flores infundibuliformes, 7-7,5 cm compr.; tubo do hipanto 4-10 $\mathrm{mm}$ compr.; tépalas púrpuras,oblanceoladas; verticilo externo com 14-16 nervuras principais, ápice acuminado,região papilar em faixa longitudinal; tépala superior sem cintura, 3,5-5 × 1-1,2 cm, tépalas laterais inferiores 3,7-5,4 $\times 1 \mathrm{~cm}$; verticilo interno com 10-12 nervuras principais,ápice cuspidado; tépalas laterais superiores $3,6-5,3 \times 0,8-1,4 \mathrm{~cm}$, tépala inferior 3,5-5 × 0,8-1 cm; paraperigônio presente, formado por segmentos setiformes, pareados e flanqueando os filetes na base; filetes em 4 comprimentos diferentes, anteras reniformes, ca. $5 \mathrm{~mm}$ compr.; ovário oboval; estigma trilobado. Fruto não visto.

Material examinado: RIO GRANDE DO SUL: Canela, Caracol, II.1948, fl., K. Emrich 37193 (PACA); Porto Alegre, Serraria, província Ponte Grossa, 3.II.1963, fl., G.Pabst 7294 (HB).

Habranthus ruber é caracterizada pelas flores vermelho-intenso. Pode também apresentar espécimes com inflorescências bifloras. É facilmente confundida com $H$. gracilifolius, principalmente em relação às folhas. Entretanto, $H$. ruber apresenta folhas mais largas que $H$. gracilifolius além desta última apresentar flores róseas a lilases. Morfologicamente, aproxima-se também de $H$. sylvaticus, em função da coloração púrpura e flores de 5,5-8,5 cm compr. e tépalas de 3,5-7 cm larg. Habranthus sylvaticus difere de H. ruber por apresentar bulbos globosos, folhas presentes durante a antese, bractéolas ausentes e flores crateriformes. Ocorre no Rio Grande do Sul, nos Pampas. Floresce no mês de fevereiro.
21. Habranthus sylvaticus Herbert, Amaryllidaceae. 166, 1837.

Fig. 3s-t

Bulbos globosos, 2,5-4,5 × 2,5-3,5 cm, colo 2,5-4 cm compr. Folhas verdes, lineares, ca. $12 \times$ $3-5 \mathrm{~cm}$, ápice agudo; nervuras $12-13$. Escapos $10-20(-23) \times 0,2-0,4 \mathrm{~cm}$; brácteas marromacinzentadas, 2,7-4,7 cm compr.; bractéolas ausentes; pedicelo verde-claro, 2,3-4,5 cm compr. Flores crateriformes, 5,5-8,5(-10,5) cm compr.; tubo do hipanto 1,5-2 cm compr.; tépalas roxas a violetas com base esverdeada, obovais a oblanceoladas; verticilo externo com 15-21 nervuras principais, ápice com apículo conspícuo, região papilar em faixa longitudinal; tépala superior sem cintura, $(4,5-) 6,3-6,8(-9,2) \times 0,9-1,8 \mathrm{~cm}$, tépalas laterais inferiores $(4,7-) 6,5-7(-9) \times$ 0,7-1,6 cm; verticilo interno com 11-14 nervuras principais, ápice acuminado; tépalas laterais superiores $6,8-7 \times 0,1-0,2 \mathrm{~cm}$, tépala inferior $(4,2-) 6,5-6,8(9,6) \times 0,7-1,6 \mathrm{~cm}$; paraperigônio presente, formado por segmentos em forma de ganchos, pareados e flanqueando os filetes na base; filetes em 4 comprimentos diferentes, anteras reniformes, 3-5 mm compr.; ovário oboval; estigma trilobado. Fruto não visto.

Material selecionado: BRASIL. BAHIA: Alagoado, estrada Casa Nova-Remanso, 41 ${ }^{\circ} 20^{\prime} \mathrm{S}$, 09 $50^{\circ} \mathrm{W}$, 18.X.1990, fl., A. Freire-Ferro et al. $1993 b$ (SPF, HUEFS); Andorinha, estrada Sítio do Açude-Santa Rosa, 1008'50'S, 3954'18'W, 30.II.2006, fl., F. França et al. 5498 (HUEFS); Canudos, cerca de $2 \mathrm{~km}$ NW na estrada para a Estação Biológica de Canudos, $10^{\circ} 01$ '58'S, 39॰09'00'W, 29.X.2001, fl., L.P. Queiroz et al. 7046 (HUEFS); Feira de Santana, Campus da UEFS, Bosque do Pau Brasil, $12^{\circ} 15^{\prime}$ S, $38^{\circ} 58^{\prime} \mathrm{W}, 12$. II.1987, fl., L.P.Queiroz 1419A (TEPB, CESJ); Morro do Chapéu, estrada nova do Parque Estadual do Morro do Chapéu,

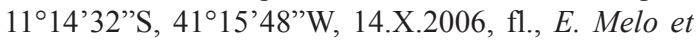
al. 4551 (HUEFS); Paulo Afonso, Estação Ecológica do Raso da Catarina, 0940’36”'S, 38²5'19'W, 30.XI.2005, fl., F. França et al. 5293 (HUEFS); Queimadas, Município de Queimadas, $10^{\circ} 59^{\prime} \mathrm{S}$, 39॰38'W, 1.XII.1992, fl., M.M. Arbo et al. 5489 (SPF). GOIÁS: Cocos, Fazenda Trijunção, próximo a sede, 14'53'S, 4552'W, 28.IX.2001, fl., T.S. Filgueiras \& D. Alvarenga 3645 (IBGE, SGO, FLAS, CEN, RB, FTG); Flores, Fazenda Cachoeirama, Lagoa 1, 14¹7'53's, 4659'24”'W, X.2004, fl., R.C. Mendonça et al. 5807 (IBGE, RB); Posse, cerrado próximo ao aeroporto de Posse, $14^{\circ} 06^{\prime} 58^{\prime}$ 'S, 46²0'48”'W, 16.X.2001, fl., R.C. Mendonça et al. 4444 (IBGE). MARANHÃO: Santa Quitéria, Fazenda Marflora, I.1993, fl., Pereira \& Paula 2345 (IBGE, RB, UB); Timon, 0505'12”S, 42॰59'46”'W, 12.XII.2002, fl., C.G. Lopes et al. 247 (SPF). MINAS GERAIS: Diamantina, Estrada para São 
João da Chapada, XI.1985, fl., J.R. Pirani et al. 40287 (HUEFS). PERNAMBUCO: Buíque, Parque Nacional de Catimbau, Trilha dos Canyons e das Conchas, V.2004, fl., A. Alves-Araújo \& Martins 6 (UEC). PIAUÍ: Boa Hora, estrada de Caríba, XI.1999, fl., F. França et al. (UEC), Oeiras, Malhada da Onça, 0700'69”S, 4204'13”W, I.2008, fl., F.C.S. Oliveira \& Santana 254 (TEPB); São José do Piauí, estrada São José-Inhuma, 28.X.1999, fl., M.R.A. Mendes et al. 143 (UEC); Teresina, Parque Ambiental de Teresina, fl., 4.XII.2002, M.C. Abreu \& C.G. Lopes 10 (SPF). RIO GRANDE DO NORTE: Santana, Sítio do Sr. Otílio, I.1968, fl., N. Lima 29 (UB).

Habranthus sylvaticus, juntamente com $H$. bahiensis, $H$. conterminus, $H$. goianus e $H$. ruber são as únicas espécies brasileiras que possuem flores vermelho-intenso. Além disso, apresentam filetes em 4 comprimentos diferentes. Habranthus goianus e $H$. sylvaticus apresentam flores crateriformes e $H$. bahiensis, $H$. conterminus e $H$. ruber apresentam flores infundibuliformes. Habranthus goianus se diferencia de $H$. sylvaticus pela ausência de folhas durante a floração, tubo do perigônio 8,5-9 mm e tépalas oblanceoladas. Já $H$. bahiensis apresenta folhas filiformes, com 6-8 nervuras principais e tubo do perigônio 4-5 $\mathrm{mm}$. H. conterminus apresenta tépalas oblanceoladas, as externas com 12-13 nervuras principais, anteras elípticas e estigma trífido. Deferencia-se de H. ruber, entre outras características, pelos bulbos ovais, escapo até 34,5 cm compr. e presença de bractéolas, presentes nessa. Registrada para Bahia, Goiás, Maranhão, minas Gerais, Pernambuco, Piauí e Rio Grande do Norte, na caatinga e cerrado, em solo arenoso e latossolo vermelho-amarelo, aos 500-1.000 m de altitude. Floresce em maio e de setembro a fevereiro.

\section{Agradecimentos}

Ao Conselho Nacional de Desenvolvimento Científico e Tecnológico (CNPq), a concessão de Bolsa de Produtividade em Pesquisa do segundo autor (Processo: 300976/95-0) e à Coordenação de Aperfeiçoamento de Pessoal do Nível Superior (CAPES), a concessão da bolsa de Doutorado da primeira autora.

\section{Referências}

Amaral, A.C. 2007. Amaryllidaceae Jaume St.Hil.: levantamento das espécies do Distrito Federal, Brasil, e estudos de multiplicação in vitro. Dissertação de Mestrado. Universidade de Brasília, Brasília. 132p.

Arroyo, S.C. 1990. Habranthus (Amaryllidaceae) en Argentina y Uruguay. Parodiana 6: 11-30.
Chase, M.W.; Reveal, J.L. \& Fay, M.F. 2009. A subfamilial classification for the expanded asparagalean families Amaryllidaceae, Asparagaceae and Xanthorrhoeaceae. Botanical Journal of the Linnean Society 161: 132-136.

Dutilh, J.H.A. 1996. Biossistemática de quatro espécies de Hippeastrum Herb. (Amaryllidaceae). Tese de Doutorado. Departamento de Botânica, Universidade Estadual de Campinas, Campinas. $153 \mathrm{p}$.

Dutilh, J.H.A. \& Assis, M.C. 2005. Liliaceae s.l. In: Wanderley, M.G.L.; Shepherd, G.J.; Melhem, T.S. \& Giulietti, A.M. (eds.). Flora Fanerogâmica do Estado de São Paulo. RiMa, São Paulo. Pp. 244-256.

Dutilh, J.H.A. \& Oliveira, R.S. 2013. Amaryllidaceae. In: Lista de Espécies da Flora do Brasil. Jardim Botânico do Rio de Janeiro. Disponível em $<$ http://floradobrasil.jbrj.gov.br/jabot/floradobrasil/ FB4352>. Acesso em 20 novembro 2013.

Dutilh, J.H.; Fernandez, E.P.; Penedo, T.S.A.; Moraes, M.M.V. \& Messina, T. 2013. Amaryllidaceae. In: Martinelli, G. \& Moraes, M.A. (orgs.). Livro Vermelho da Flora do Brasil. Instituto de Pesquisas Jardim Botânico do Rio de Janeiro, Rio de Janeiro. Pp. 126-139.

Flagg, R.O.; Smith, G.L. \& Flory, W.S. 2007. Flora of North America. Efloras. Disponível em $<$ http:// www.efloras.org/florataxon.aspx?flora $>$. Acesso em 20 novembro 2013.

Fundação Biodiversitas. 2005. Lista da Flora Brasileira Ameaçada de Extinção. Relatório final de Atividades. Belo Horizonte, Minas Gerais. Disponível em $<$ http://www.biodiversitas.org.br/florabr/grupo3fim. asp>. Acesso em 20 novembro 2013.

Meerow, A.W. \& Snijman, D.A. 1998. Amaryllidaceae. In: Kubitzki, K. (ed.). The families and genera of vascular plants. Monocotyledons - Lilianae (except Orchidaceae). Springer Berlin Heidelberg, Hamburg. Pp. 83-110.

Meerow, A.W.; Fay, M.F.; Charles, L.G.; Li, Q.-B.; Zaman, F.Q. \& Chase, M.W. 1999. Systematics of Amaryllidaceae based on cladistic analysis of plastid sequence data. American Journal of Botany 86: 1325-1345.

Meerow, A.W.; Guy, C.L.; Li, Q.- B. \& Yang, S.L. 2000. Phylogeny of the American Amaryllidaceae based on nrDNA ITS sequences. Systematic Botany 25: 708-726.

Meerow, A.W. 2004. Alliaceae, Amaryllidaceae. In: Smith, N.; Mori, S.A.; Henderson, A.; Stevenson, D.Wm. \& Heald, S.V. (eds.). Flowering plants of the neotropics. The New York Botanical Garden, New Jersey. Pp. 408-412.

Oliveira, R.S. 2006. Flora da Cadeia do Espinhaço: Zephyranthes Herb. \& Habranthus Herb. (Amaryllidaceae). Dissertação de Mestrado. 
Universidade de São Paulo, São Paulo. 165p.

Oliveira, R.S. \& Sano, P.T. 2009. Two new species of Habranthus (Amaryllidaceae) from the Espinhaço Range, Brazil. Kew Bulletin 64: 537-541.

Ravenna, P. 1967. Contribuições ao estudo das Amaryllidaceae da América do Sul. Sellowiana 19: 25-36.

Ravenna, P. 1988. New species of South American Habranthus and Zephyranthes (Amaryllidaceae). Onira 1: 53-56.

Ravenna, P. 1999a. New species of Zephyranthes and Habranthus (Amaryllidaceae) I. Onira 3: 52-61.

Ravenna, P. 1999b. New species of Zephyranthes and Habranthus (Amaryllidaceae) II. Onira 3: 62-67.

Ravenna, P. 2001. New species of Zephyranthes and Habranthus (Amaryllidaceae) III. Onira 6: 38-43.
Ravenna, P. 2002. New species of Zephyranthes and Habranthus (Amaryllidaceae) IV. Onira 6: 41-43.

Ravenna, P. 2003. Decisive proof on the validity of Amaryllis over Hippeastrum as mainly a South American genus, including new species and new records of Amaryllidaceae from Argentina, Brazil, and Paraguay. Onira 9: 9-20.

Seubert, M. 1847. Amaryllidaceae. In: Martius, C.F.P.; Eichler, A.G. \& Urban, I. (eds.). Flora Brasiliensis. F. Fleischer, Lipsiae. Vol. 3, p. 1. Pp. 142-163.

Thiers, B. 2013. [continuously updated]. Index Herbariorum: A global directory of public herbaria and associated staff. New York Botanical Garden's Virtual Herbarium. Disponível em $<$ http://sweetgum.nybg.org/ih/>. Acesso em 20 novembro 2013. 